
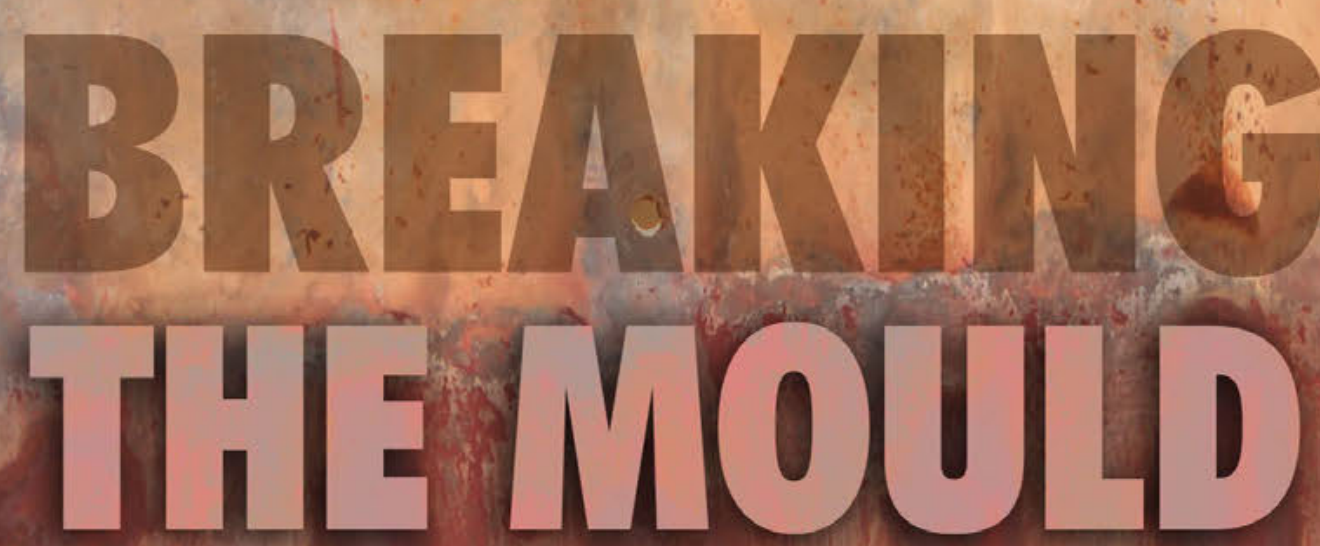

\title{
The Role of Scenarios in
}

Shaping South Africa's Future

\section{Nick Segal}


e 


\section{Comments on Breaking the Mould:}

Adam Kahane (author of Solving Tough Problems and partner in Generon Reos, Boston)

"Nick Segal's excellent monograph explores an important emerging field of social change theory and practice: how government, business and civil society leaders can work together to deepen their understanding of possible futures and thereby act effectively to bring forth better futures. The South African experience with such "scenario thinking" during the transition towards democracy provides vital lessons both for South Africans and for others engaged in the struggle for a better world."

Mamphela Ramphele (Chair of Circle Capital and former Vice-Chancellor of the University of Cape Town and Managing Director of the World Bank)

"This insightful study is an important and timely reminder of the potential power of the scenario method as well as of the value that three very different projects brought to South Africa's transition, notably in its economic dimensions. Given the country's present uncertainties, is this not an appropriate moment for a fresh exercise that encourages out-of-the-box and honest thinking particularly with respect to the huge challenges we still face in building our social capital? If so, the monograph also offers useful and practical guidance on design and conduct of such a project."

Philip Spies (former Director of the Institute for Futures Research, Stellenbosch University)

"This is a very interesting and stimulating document on important aspects of scenario-based change management in South Africa during the watershed years leading up to 1994.

"South Africa can rightfully claim that one of the important co-producing factors that contributed to its peaceful transition - and also contributed to the realistic (non-populist) policies that followed in the years after transition - was the use of scenarios in private and public sector deliberations and planning over the period 1980-94. This publication tells much of this story and moreover presents 'behind the scene' insights into the development of three major exercises: the Anglo American, Nedcor/Old Mutual and Mont Fleur scenarios. Congratulations to the author!"

Willie Esterhuyse (Professor Emeritus, University of Stellenbosch)

"Nick Segal's study is a great contribution to a better understanding of the development of scenarios and their impact on economic, social and political thinking. Of particular significance is the insight he presents on South Africa's transition and the development of our political economy.

"The book is written by someone who not only understands the topic well but who is gifted with an ability to communicate his insights in a very clear and illuminating manner. If you are seriously interested in policies and processes affecting our country, Segal's book is a must." 


\title{
BREAKING THE MOULD \\ The Role of Scenarios in Shaping South Africa's Future
}

\author{
NICK SEGAL
}


BREAKING THE MOULD: The Role of Scenarios in Shaping South Africa's Future

Published by SUN PReSS, an imprint of AFRICAN SUN MeDIA (Pty) Ltd., Stellenbosch 7600

www.africansunmedia.co.za

www.sun-e-shop.co.za

All rights reserved. Copyright $\odot 2007$ Nick Segal and SA Node of the Millennium Project

No part of this book may be reproduced or transmitted in any form or by any electronic, photographic or mechanical means, including photocopying and recording on record, tape or laser disk, on microfilm, via the Internet, by e-mail, or by any other information storage and retrieval system, without prior written permission by the publisher.

The study on which this book is based was initiated and commissioned by the SA Node of the Millennium Project and the African Futures Institute

First edition 2007

ISBN: 978-1-920109-92-9

e-ISBN: 978-1-920109-44-8

DOI: $10.18820 / 9781920109448$

Set in 11/13 Myriad Pro

Cover design by llse Roelofse

Cover image $\odot$ Diana Segal

Typesetting by AFRICAN SUN MeDIA (Pty) Ltd.

SUN PReSS is an imprint of AFRICAN SUN MeDIA (Pty) Ltd. Academic, professional and reference works are published under this imprint in print and electronic format. This publication may be ordered directly from www.sun-e-shop.co.za

Printed and bound by ASM, Ryneveld Street, Stellenbosch, 7600 
Foreword

Introduction 1

1. The Scenario Method …............................................................................ 5

2. South Africa in the 1980s: The High Road/Low Road Scenarios ....... 11

3. South Africa in the Early 1990s: The New Emphasis on the Economy

4. South Africa in the Early 1990s: The Nedcor/Old Mutual Scenarios 35

5. South Africa in the Early 1990s: The Mont Fleur Scenarios 45

6. Scenarios and the Political Economy 59

7. Design and Execution of Public-Domain Scenarios 65

Bibliography 71

Annex A: List of Interviewees 75

Annex B: Nedcor/Old Mutual Scenario Team 79

Annex C: Mont Fleur Scenario Team 81

Annex D: South African Scenarios 
In 2006 the South Africa Node of the Millennium Project, in association with the Africa Futures Institute, commissioned a study on the effectiveness of the scenario method as a tool for public debate and policy formulation. Consistent with the origins and purposes of the Millennium Project - a think-tank comprising over 30 groups (or Nodes) around the world, dedicated to exploring global futures - as well as our own mission of building capacity in futures studies in South Africa and the wider region, our purpose was simple.

Based upon case studies of past scenario projects, each located in its particular socio-political context, we wanted to illuminate the circumstances in which scenarios were a useful device for policy planning and strategic thinking, as well as the factors that must be borne in mind in designing and carrying out scenario projects. More particularly, what general lessons could be drawn about the nature and objectives of the sponsors, the timing of the work, the choice of participants, the style of facilitation, the methods adopted and the dissemination techniques used, in order to ensure that any new exercise would have its intended impact? Through this means, our intention was to inform the design and execution of future scenario studies.

The study was financed principally by the Anglo American Chairman's Fund, to whom we express our deep appreciation.

It was carried out by Nick Segal, whom we selected because of his extensive and high-level experience in South Africa and internationally in the field of public policy and associated socio-economic analysis. 
We are pleased to publish the study, which we believe not only makes a distinctive contribution to the art and science of futures thinking but also shreds fresh light on South Africa's evolving political economy.

JP Landman

Geci Karuri

Bob Day

Directors, SA Node of the

Millennium Project

MILLENNIUM PROJECT

SOUTH AFRICA NODE
Alioune Sall

Director, African Futures Institute

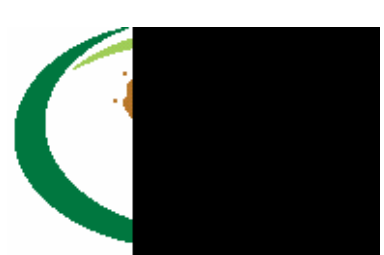

AFRICAN FUTURES INSTITUTE 
South Africa's transition from an oppressive, isolated and racially discriminatory system of government to an internationally-oriented liberal democracy took place over many years. The story is best known internationally for the dramatic changes introduced unexpectedly by the prevailing regime in 1990, for the emergence of Nelson Mandela as a figure of heroic spirit and as a force for reconciliation and stability, and for the subsequent implementation of internationally exemplary macroeconomic policies. But there are many other aspects to the story, and many factors that underlay the changes.

This report is about one set of such factors, viz the contribution of public-domain scenario exercises to the transition. This is prima facie an unusual topic, certainly not one that features prominently in the many published accounts of the period, ${ }^{1}$ and so it is important to understand how and why the project came about.

South Africa seems to be unusual in the widespread use of scenarios for public policy purposes. Over the past two decades numerous exercises have been undertaken, some at the level of the political economy as a whole, while others have focused on specific sectors or issues. In order to make manageable the commissioned study, it was essential to select the scenario projects to be covered. Because of the importance of 'context', the view was reached that these should be in the same field so that the research and consultations could be concentrated rather than fragmented.

Of the candidate exercises, three stood out:

- the Anglo-American High Road/Low Road scenarios of the mid-1980s, published in 1987 as The World and South Africa in the 1990s 
- the Nedcor/Old Mutual project of 1991-92, published in 1992 as South Africa: Prospects for a Successful Transition

- the independently funded Mont Fleur Scenarios of 1991-92.

Each of them dealt with the national political economy. They were each well known and, anecdotally, had all contributed to the public debate of the time and had exercised influence. They had been the subject of an earlier study, ${ }^{2}$ which did not, however, seek to interpret the scenarios in the political-economic context of their times and was thus somewhat narrowly focused. Consequently, there was no hesitation on the part of the clients and the author in choosing them for the case studies.

In the course of the ensuing fieldwork, another scenario project of the same 'species' was identified - SA2020 - undertaken in 2003-04. This was included too, though in less depth, because it had not achieved the same standing as the other three.

So, this is a hybrid paper. Its rationale is narrow: how best to carry out scenario work. But its canvas is wide, because of the all-important matter of 'context'. My hope is that it makes a contribution at both levels.

For completeness, thumbnail sketches have been compiled of the other public scenario exercises carried out in South Africa since 1990. They are presented in Annex D.

\section{Methodology}

The approach adopted was straightforward. In addition to studying the scenarios themselves and reading widely, interviews were held (where relevant and feasible) with the respective sponsors, facilitators and participants, with politicians, with independent commentators and with members of the target audiences. These consultations were held mostly in the period July - November 2006. Annex A lists the individuals consulted.

In order to encourage frankness, interviewees were assured that that they would not be directly quoted in the published report, or have views attributed to them personally without prior clearance. In the event, I have judged it unnecessary to cite individuals in supporting all facets of the narrative told here as well as the conclusions reached.

For the record it should be stated that I had no involvement in any of the scenarios reviewed and nor did I attend any presentations of them. I was abroad for many years, returning to South Africa only in December 1991. Although I subsequently got to meet several of the key players in the different exercises, as well as political, labour and business leaders, and although I was responsible for a corporate scenario exercise in the mid-1990s, I came to this study with 
everything to learn and without preconceived ideas. The facts recorded here and the judgments and conclusions reached are thus the direct result of the study itself, influenced of course by my prior experience in the public policy domain and by my general knowledge of South African affairs.

It is important to understand that this report is not a critique of the content of each of the scenarios studied. Thus it does not pursue such issues as whether the right questions were asked, whether there were significant omissions or other 'mistakes' and whether with hindsight they were wide of the mark of what actually transpired subsequently. Rather its thrust is on the contribution that each made to the political economy and on identifying those factors that shaped this contribution.

The draft report was written in December 2006 - January 2007 and reviewed by the steering committee in February 2007. In addition, during the period February - April 2007 the draft was reviewed at the author's request by a number of individuals, a few of whom had been directly involved in the scenarios studied and in some cases had also been consulted in the course of the study. The revised version was then, at the request of the steering committee, formally critiqued by four independent individuals. The report was finalised in August 2007.

\section{Structure of the report}

Following this introduction, the next chapter discusses in general terms the scenario method as an aid to planning. Chapter 3 presents the High Road/ Low Road exercise of the mid-1980s and assesses its impact at the time and subsequently. Chapter 4 discusses the evolution, from the mid-1980s onwards, of the economic philosophy of the future government, in order to provide the appropriate context for the Nedcor/Old Mutual and Mont Fleur projects. The following two chapters are devoted to examining the impact of each of them. Chapter 5 also deals briefly with the SA2020 exercise. Chapter 6 draws general conclusions about the role of scenario work in the arena of the political economy, and the final chapter offers pointers for the design and execution of any such work in the future.

\section{Acknowledgments}

I express my gratitude to the study steering committee - JP Landman, Geci Karuri and Bob Day - for its advice and support, and to JP in particular for his enthusiastic encouragement. I acknowledge with appreciation the financial support of the Anglo-American Chairman's Fund and the African Futures Institute. 
I thank, too, Stephan Malherbe, chairman of economics consultancy GenesisAnalytics, for his general support and for making available Genesis staff member Sarah Truen as a researcher. In addition to being responsible for Annex D, Sarah was throughout a refreshing and constructively critical colleague.

I am extremely grateful to four sets of individuals. First, those whom I interviewed - without their generous commitment of time and thought, this report would not have been possible. Second, in addition to the steering committee, those who critiqued the first draft, viz Ann Bernstein, Graham Galer, Rudolf Gouws, Adam Kahane, Dave Kaplan, Robin Lee, Pieter le Roux, Philip Mohr, Michael Spicer, Philip Spies, Khehla Shubane, Hardin Tibbs and Bob Tucker. Third, the four individuals who reviewed the final draft at the request of the steering committee: Koffi Kouakou, Guy Lundy, Rasigan Maharaj and André Roux. Fourth, Miriam Altman and Mamphela Ramphele, who also read the final draft.

Finally, I thank my wife Diana not only for her encouragement and support (and forbearance) but also for conceiving the design of the cover based on one of her photographs.

1 The only reasonably substantive mentions I have found are in Adam and Moodley (1993), Bond (2005) and Kentridge (1993).

2 See Galer (2004). 


\section{THE SCENARIO METHOD}

\section{Introduction}

Scenarios as a planning device originated in the American military after World War II. ${ }^{2}$ The Air Force hypothesised how the enemy would behave and prepared alternative strategies accordingly. The method was adapted to the world of business planning in the 1960s by Herman Kahn of the Hudson Institute, who had been involved in the Air Force work, and later by inter alia the Stanford Research Institute. The approach was to seek to explore relentlessly all possible futures, so that decisions could be based on apparent insights into how the future would actually unfold.

It was at Royal Dutch/Shell, starting in the late 1960s, that a fresh approach was taken to scenarios. ${ }^{3}$ Shell's management recognised that, despite the sophistication of the company's planning techniques, they were unable to accommodate the growing turbulence and uncertainty in international oil markets - in effect the underlying premise had up to then been that the world was predictable and would continue broadly in line with past and current trends. In exploring how to develop a more realistic and robust approach to planning, Shell hired a remarkable French economist, Pierre Wack, whose name has become indelibly associated with the scenario technique.

The method of Wack and his team in Shell's group planning department was to examine rigorously the forces - be they political, technological, financial or whatever - driving change in the markets or sectors concerned. They would then, for given sets of assumptions, formulate a small number of different, internally logical stories (scenarios) as to how these forces could play themselves out. These stories were aimed at helping managers understand the ways in which the future would not be the same as the past and also at preparing them, 
through their enhanced grasp of the context in which they were working, to take better informed decisions as the future actually unfolded.

The underlying reasoning was that managers' mindsets had continually to be refreshed to take account of perpetually changing circumstances. Wack observed that without this managers would too easily slip into presuming that tomorrow would bring more of the same. He coined the memorable phrase "the gentle art of reperceiving" as indicative of the challenge that he as a planner faced in equipping Shell's managers with the wherewithal to think clearly and strategically in their changing environment and to take good decisions.

It was central to the Shell method that managers were not invited to 'choose' any one of the scenarios presented to them. In the same vein, probabilities were not attached to the stories, and prima facie the planners remained neutral as to the different possible outcomes: it was up to the decision-makers to digest and weigh the material and to work out for themselves how to use it.

I say 'prima facie', because there is evidence that Wack was himself not indifferent to the various scenarios created. In his formative years he had immersed himself in mystical thinking, under the tutelage of a distinguished Sufi scholar, which he subsequently refreshed regularly throughout his professional life. He came to believe that through intensely focused application of the mind and of the spirit it was possible to gain an understanding of how the future could unfold. To this endeavour he brought to bear an exceptionally wideranging, perceptive, analytical and logical intellect - altogether a formidable talent.

Wack sought to identify, in addition to underlying strategic drivers of societal change, so-called 'pre-determined elements'. To explain this concept, he used to refer to the inevitability of rising water levels down the Ganges after heavy rains in the Himalayas. He believed that part of his task as a scenario builder was, through imaginative and rigorous thinking, not only to identify these elements but also to explore their impacts. He remained open to new ideas and insights the 'gentle art of reperceiving' applied as much to himself as to the decisionmakers he was seeking to influence.

In the same spirit, Wack believed that the scenario thinker was obliged to go beyond imagining an array of possible logical futures. Simply to present such an array meant that the analyst's job had not been done properly. It was incumbent on the analyst to 'narrow the range of possibilities' so that what was presented to the decision-takers was a set of plausible futures rather than just of logical possibilities.

To reinforce this approach, Wack insisted that three scenarios should never be presented, because this would inevitably lead managers to favour the 'middle' one. He further argued that in the interests of simplicity the maximum number 
should be four. But he never overtly favoured one scenario over another - in this respect he was studiously neutral.

By all accounts Wack was something of a 'one-off'. Assisted and complemented by a few remarkable colleagues, he was able to combine logical, imaginative and intuitive thinking about the future in a way that has probably not subsequently been emulated. The general tendency has emerged in contemporary practice, in exploring the future, for the scenario process to emphasise the analytical (based on the past and perhaps the current) and the logical and not to accept, as Wack did, that it is the obligation of the scenario painter to generate fresh insights into how the future will unfold.

Curiously, Wack often used the term 'scenario planning', when in fact it is not planning at all. 'Scenario-based planning', a term he also used, captures better his work in the corporate domain in Shell. In the case of public-domain scenarios 'thinking', 'painting', 'building' or 'sketching' express more accurately what the activity is, and these will be the terms used in this study.

The team at Shell became famous both for the quality of its work, some of which was published, and for the calibre of the individuals involved. Several of them, building on their Shell experience, went on to do pioneering work internationally in futures studies, as well as in other fields such as leadership and conflict resolution. In important instances, their work went beyond the confines of a single organisation and was focused on systemic issues at the level of a region or country. Indeed, Pierre Wack himself (along with a former Shell colleague Ted Newland) played a critical role in two of the three South African scenario projects covered in depth here; and Adam Kahane, a senior member of Shell's scenario team in the post-Wack period, facilitated the third.

There seems little question that the cumulative impact of the scenario work was to change the culture of top management at Shell. ${ }^{4}$ It would be an exaggeration to claim that particular business decisions were directly influenced. However, because managers were offered a coherent framework for thinking about their environment and their minds were opened to trends and to issues they had not previously been aware of, the scenario work came to play an important part in setting the broad direction of the corporation. More specifically, since at any one time there are several scenarios and only one strategy, it was invaluable to test the strategy against each scenario and hence to understand better the risks of adopting the strategy. Similarly, Shell found that scenarios they had prepared on countries or regions could, if shared with a particular government, be a useful tool in building a sound relationship with that government. 


\section{Four characteristics of scenarios}

As the scenario method devised at Shell has come to be applied in new and different environments, so new variants have been developed especially in terms of objectives and processes. Different as they may be, they invariably exhibit four key characteristics in lesser or greater measure. ${ }^{5}$

The first is essentially the Shell model - scenarios as a tool to facilitate strategic decision-making by top management. Here the institutional context is likely to be a single organisation, with a clear decision-making hierarchy. and a planning process that allows for research or other methods to analyse the drivers of systemic change.

The second is scenarios as an advocacy tool, whether for an individual organisation or for a wider system. Here the planners or the decision-makers become persuaded of the 'correctness' of a particular scenario and hence argue for it and for the associated decisions to help bring it about. Or, alternatively, the rationale for the exercise in the first place is to advance a particular viewpoint, and the scenario process is used as a convenient vehicle to this end. The underlying philosophy is that the players in the scenario 'system' can, through appropriate actions, actively help shape the future in the desired direction.

Third is scenarios as a tool for generating awareness with a view to building understanding and perhaps eventually consensus. The challenge is to reconcile diverse perspectives on a particular issue, which could be as broad as the future of a country. In a neutral but overtly problem-solving environment, telling stories that reflect the participants' different perspectives and then subjecting the stories to objective scrutiny as to their plausibility is potentially an effective way of accommodating differences and generating a shared understanding of the problem and a shared view of the future. Critical to the success of this approach are the style and substance of the process facilitator, and the rapport established with and among the participants. Whereas the previous two categories are likely, though not necessarily, to be based on rigorous research, this third type typically depends on the participants' bringing their experience and prior knowledge as inputs to the process.

The fourth characteristic is that scenarios are exercises in intellectual enquiry. Of course, all scenario projects are exercises in learning, especially for the participants and prospectively for the audiences. But the fourth characteristic is different because, even though the issues debated may be real and important, the scenario process - either in its conduct or its dissemination, or both - is not connected to the institutions or the decision-makers concerned. Consequently, no matter how good the work and how stimulating the experience for the participants, the output has no discernible impact externally and indeed may not even be generally known. 


\section{Concluding comments}

The scenario method, as developed initially for planning purposes in the military, depended for its substance on the quality of the research and the empirical base. To a significant extent this was also the case for scenarios evolved in the corporate environment at Shell, though here the process of debate in the management team came to be recognised as critical and consequently so, too, was the need to accommodate behavioural and psychological factors in conducting that debate. Adaptation of the method to societal issues and environments makes these process issues of overriding importance, and hence the value of the work depends critically on design and management of the process.

These considerations point to a fundamental issue in the make-up of the participants in a scenario project, viz the balance between those chosen for their subject expertise and those chosen because of the interests they represent and the influence they can exert. Especially in projects in the public domain, it is clear that it is not only technical experts who can offer insights; these will come from all the other stakeholders too.

These different features will be evident in the scenarios reviewed in the ensuing chapters.

1 In the final stages of revising this study, my attention was drawn to two relevant publications. The first was written by Shell International as an explanation of the scenario methods they had developed over three decades - see Shell International ( 2003). The second presents an overview of the techniques of scenario development see Bishop et al (2007).

2 See Schwartz (1991).

3 See Wack (1985a, 1985b). This section is based also on my interviews with Kahane and Tucker and on my correspondence with Tibbs, who was a close associate of Wack and who wrote an insightful obituary of him (see Tibbs 1998).

4 Interviews with Kahane and Moody-Stuart. See also Shell International (2003).

5 This builds on a classification suggested by Pruitt (2000). 


\section{SOUTH AFRICA IN THE 1980s}

\section{The High Road/Low Road Scenarios}

\section{South Africa in crisis ${ }^{1}$}

The early through the mid-1980s were a fraught time in South Africa's history. The 1970s had seen an increasingly poor economic performance, in sharp contrast to the buoyant 1960s, resulting inter alia in high levels of unemployment and declining GDP per capita. Numerous incidents, actions and trends served to make South Africa an increasingly unhappy and isolated place, in which the government ruled by force. Such events included the Soweto riots of 1976, which marked a turning-point in the posture of urban blacks towards the government and also resulted in the exodus of township youth leaders and others to join the ANC and other opposition groups in exile; massive investment in further implementation of apartheid's grand 'Bantustan' plan; costly build-up of military capacity and rising intervention in the so-called frontline states; continuing large-scale migration to urban areas despite the pass laws; a willingness on the part of the state to use ever harsher methods to suppress political opposition; strengthened international protests against apartheid and government brutality both locally and in the region; and the imposition of trade and financial sanctions and of obstacles to the international movement of South African citizens, as well as the banning of South Africa from participation in international sporting events.

Against this background, in the early 1980s the government of PW Botha felt that it could introduce limited political reforms without weakening its grip on power. At the heart of the changes was a new constitution that extended 
modest political rights to the Asian and Coloured population groups, but left the black African population (other than in the so-called 'homelands') without a political voice. Moreover, the arrangements put in place to govern the black townships were deeply offensive to the local population and relied for their implementation on 'co-option' of typically unpopular and corrupt individuals. These new arrangements, which caused bitter divisiveness in black communities, were accompanied by a new policy that required the black urban areas to be financially self-sufficient, which in turn meant the imposition of significantly higher housing rents.

These changes stimulated the revival of black political opposition at grassroots level. In mid-1983 the United Democratic Front (UDF) was formed out of hundreds of diverse local organisations in order to campaign against the new constitution and the new system of township administration and financing. Despite vigorous and widespread protests led by the UDF, the government decided to proceed with its plans. It was not long before the protests turned into violent confrontations with the police. For over three years, starting in late 1983, South Africa went through civic turmoil, as the UDF, having consolidated its position through recruitment of even more organisations, deliberately set out to make the townships ungovernable and as the government drew in the army and twice declared a state of emergency.

Throughout these years, despite being so beleaguered at home and so pilloried internationally, the regime continued to enjoy the backing of powerful Western governments - notably the USA, UK and Germany - essentially because of the Cold War and because of the strategic importance attached to South Africa's production of minerals and its geographic position at the tip of the continent. There was a nervousness that the black leaders were radicals acting at the behest of the Soviet Union, and the predisposition was quietly to encourage incremental reform. (The emergence of Gorbachev in 1985, with his radical notions of perestroika and glasnost, were in due course to change this perception, as well as to have crucial impacts on left-wing thinking in South Africa.)

In 1985 PW Botha made a much-heralded speech which, contrary to the advance signals and perhaps encouraged by the quiet support he was receiving from Reagan and Thatcher in particular, belligerently showed the world that he had no intention of yielding to pressure from any source and of making changes other than those of his own design and at his own pace. A swift and direct consequence of this was the calling-in by international banks, already being pressurised by international activist groups to disengage from the country, of their extensive loans to South Africa. Although a repayment schedule was negotiated within a few months, the damage to the economy was profound, not least because of the impact on the confidence of the white establishment. Already frightened by the continuing civil disorder, whites felt increasingly 
isolated internationally. These sentiments were reinforced by the disastrous outcome in 1986 of the visit of the so-called Eminent Persons Group, appointed by the Commonwealth to serve as mediators in helping resolve the political crisis.

Nevertheless, various attempts were made by some sections of the white establishment, in defiance of the government, to reach out to the ANC in exile. One of the most significant involved a meeting, facilitated by President Kaunda, in Zambia in late 1985 between a South African business delegation and top ANC officials. At much the same time the principal opposition party met the ANC in Lusaka. A third was in 1987 when a group of Afrikaner leaders and intellectuals, including the then leader of the opposition party Frederik Van Zyl Slabbert, met the ANC in Dakar. These were all highly publicised events.

Of critical importance, and kept secret at the time, conversations commenced in Britain in 1987 between the ANC (led by Thabo Mbeki) and prominent Afrikaners, including some with close connections to the government. The talks originated in the government's desire to gain an insight into the ANC's thinking on the prospects for a negotiated settlement. The leading role in approaching the ANC on behalf of the government and in winning Mbeki's confidence was played by Willie Esterhuyse, a former member of the Broederbond and a philosophy professor at Stellenbosch University. The ANC in turn was pleased to have a channel (Esterhuyse) through which it could convey 'messages' to Pretoria. The talks - which took place in the congenial environment of an English country house by courtesy of Consolidated Goldfields, a mining company with the bulk of its assets in South Africa - continued until February 1990, and in fact it was there that Mbeki, with Esterhuyse among others, saw on television FW de Klerk's parliamentary speech announcing the unbanning of the ANC and the release of Mr Mandela.

\section{The High Road/Low Road scenarios ${ }^{23}$}

The first years of the above story provide the domestic context for the decision in the early 1980s by the Anglo American Corporation, by far the largest company in South Africa, to embark on a scenario project. Interestingly, however, it was not the problematic local political scene that led to the decision but rather the recognition by management, prompted by the late 1970s escalation in world oil prices and the subsequent slump in commodity markets (but not in the price of gold), that international economic turbulence and uncertainties were such that conventional approaches to business planning were no longer adequate. New ways of thinking about future investment decisions had to be devised. 
Anglo's London office was aware of the pioneering scenario work done by Shell. The upshot was that Pierre Wack and Ted Newland, both on the point of retiring from Shell, made a presentation in about 1982 to Anglo's executive committee (Exco) in Johannesburg. This led to their appointment as consultants to Anglo to formulate global scenarios to provide the context in which Anglo could plan more effectively.

A large-scale exercise was mounted involving, in addition to Wack and Newland, a variety of international experts, individuals from the research and economics unit at Charter Consolidated in London, and a team from Anglo's head office in Johannesburg. The project was coordinated in Johannesburg by Clem Sunter, then in the chairman's office as secretary to Exco. Michael O'Dowd, Bobby Godsell, Michael Spicer and Jim Buys were among the members of the head office team.

The bulk of the effort was focused on the formulation of global scenarios, based on analysis of key 'drivers' such as demography, technology and societal values, of developments in what were then regarded as the three main actors on the world's economic stage (Japan, USA and USSR), and also of what were the ingredients of success for 'winning' nations and for world-class companies.

This work provided a framework for the South African scenarios. These focused on the choice facing the country as to whether, through consultation and negotiation, it did what was necessary to travel on the 'high road' to a non-racial democracy and rising prosperity, or whether it continued as a repressive, centralised society and controlled economy which would take it onto the low road' of confrontation, conflict and falling incomes leading inexorably to a 'waste land'.

Clem Sunter first presented the scenarios inside Anglo and its associated companies in 1986. After one of these sessions the suggestion was made - by the chief executive of the sugar producer Tongaat Hulett - that Sunter make a presentation to the Natal-Kwazulu Indaba, in which local political and business interest groups were debating inter alia the merits or otherwise of combining the two 'territories' into a single regional legislature. Sunter referred the invitation to Anglo's chairman Gavin Relly, who was initially reluctant because it had never been the intention to take the project into the public domain and perhaps also because he was mindful of Anglo's problematic reputation among many sections of society except for the white English-speaking community.

Relly was, however, a deep and broad thinker. He was, in the tradition of the corporation's philosophy and values, keenly aware of the socio-political context in which Anglo operated. It was he who, against much opposition, had led a delegation of white businessmen to meet the ANC in Zambia in September 1985. And, in addition to having commissioned the scenario work in the first place, he had also sponsored two politically forward-looking projects, one on 
negotiations for conflict resolution and the second on constitutional options. It is thus not surprising that Relly eventually agreed, and Sunter made his presentation to the Indaba in July 1986.

Immediately after that presentation, five of the 29 different delegations present asked Sunter to give the same talk to their respective constituencies. Relly agreed not only to this but also took the decision that Sunter should make the presentation in 'high' places, as well as to virtually any group who requested him to do so. Word of mouth spread fast. Within less than a year Sunter gave the talk to some 230 audiences consisting of 25000 to 30000 people, and Jim Buys and Michael Spicer were each enrolled as separate presenters to enable Anglo to respond to the innumerable requests.

The audiences varied widely: the Cabinet, government departments, 'homeland' governments, political parties and clubs and associations across the country. The great majority of audiences were white.

In addition Sunter wrote a book, published in 1987, based on the presentation, and later that same year a video was made of one of his public presentations. Sunter continued giving the talk over the next few years - one of these was to Nelson Mandela in January 1990 shortly before his release, and another to the SA Communist Party in July of the same year. He also wrote a second book ${ }^{4}$ reflecting on South Africa's progress along the 'high road' ten years after the scenarios were first presented publicly.

The financial costs of the entire project, embracing the work itself and then the massive effort to communicate it, are not known. There can be no doubt, however, that they would have amounted to several million rand even in the currency of that period.

\section{Impact of the scenarios 5,6}

There seems little doubt that the presentations made a big impression on the audiences. This arose partly out of their content. White South Africans hated their growing isolation in what was otherwise an increasingly interconnected world, and it made them feel good to be exposed to leading thinking on the critical influences on global change and economic competitiveness. And, because the message with respect to South Africa was ultimately positive, showing that the people of the county had it in their own power to avoid Armageddon and to get onto the 'high road', it made them feel more optimistic about the future despite the desperate state of affairs then prevailing.

But mostly the impact derived from the style of the presentation. There were several dimensions to this. 
First, the language used was simple and accessible. Complex topics were conveyed in a way that made them understandable to lay people.

Second, the fact that so much time was spent on the global scene not only gave authority to the presenter but also meant that the focus was not exclusively on South Africa.

Third, the treatment of South Africa was non-prescriptive. There was no overt criticism of anybody, but rather an invitation (perhaps an exhortation) to the country's citizens to shape the future proactively.

Fourth, the means of conveying the South African scenarios was principally a brilliant diagram which showed the two different trajectories and how they related to each other, and also how the political and economic domains interconnected. It was a powerful graphic depiction of the choices facing the country at the time, and indeed remains valid today.

Finally, the most distinctive feature was the style of Clem Sunter himself. With few exceptions, the people I have consulted recall with admiration his skill as a communicator. Light-touch, witty, good with words, quick on his feet, never talking down to his audience and always willing to interact with it, and a good listener, Sunter was able to hold people's attention through what otherwise could have been rather abstract and technical arguments. (The 'exceptions' were typically academics or individuals of left-wing inclination who found the presentation altogether too slick and up-beat for their comfort.)

The question remains: did the Anglo scenarios make any impact on the country as a whole? Did they contribute to changing the mindset of key decision-makers and their advisors, and as such contribute to changing the country's politics? Did the fact that they went down well with audiences of so many different kinds make any difference as to what the various groups thought about their respective worlds? If the scenarios had not been taken into the public domain, would South Africa's political evolution have turned out any differently?

There clearly is not a single or simple answer to any of these questions. Moreover, the topic has to be explored for each of the relevant 'audiences' or interest groups concerned. My consultations have identified two broad groups that were influenced by the scenario exercise. The first was the white community, mostly the English-speaking and materially well-off sections. As already suggested, they related well to both the content and style of the presentation, and were given grounds for greater optimism about the future. The political significance of this group was, however, modest - even the business leaders among them had very little if any contact with government and certainly were in no position to lobby government.

The second group, more importantly, was the government itself. The evidence here is clear. Although never formally debated in the Cabinet, the presentations 
were made variously to ministers and officials and were debated in bodies such as the President's Economic Advisory Council. The presentation was in general favourably regarded because of its coherence and range, because it stimulated awareness of a rapidly changing world, because it offered an intellectual structure for thinking about the need for political change and the dimensions of that change, because it pointed clearly to the need to move towards a marketbased economic system given the globalising world economy, because it highlighted the fact that the country was already sliding down the 'low road' and because the 'high road' was so obviously the only desirable alternative. The positive interpretation of the message was that the country had to 'adapt and win' rather than simply 'adapt or die'.

As already observed, in the mid-1980s the government was under huge pressure from many sources. Its management style was hierarchical and one of day-today crisis management and fighting for political survival. There was not a culture of vigorous debate in the Cabinet, and economic matters were accorded little if any weight. It certainly was not a time when reflection about economic philosophy and competitiveness and about the inter-connectedness of political and economic issues was encouraged. For those in senior positions who were, nevertheless, deeply (even if privately) worried about the deteriorating political and economic position, the scenarios came as a breath of fresh air and helped underscore their conviction that change was essential.

It would be an exaggeration to suggest that the scenarios made a decisive contribution to the thinking not just of the government in general but also of key decision-makers. But they clearly made some contribution and, as such, must be regarded as one of the positive factors that encouraged the government eventually to embark on the political transition.

One of the factors that made some in government, perhaps senior officials more than politicians, receptive to the Anglo American scenarios was that there was already a degree of familiarity with scenario-based planning. Structured approaches to thinking about the future had been initiated by the military and the security services in the late 1970s. But their work remained tightly held within the units undertaking it and was not shared across government as a whole.

But in the early 1980s a fresh approach to futures thinking was initiated in the State Security Council, which was developed throughout the decade. This was undertaken across government departments, using a small number of core staff but mostly outside experts covering many disciplines - Philip Spies, the doyen of South Africa's futurists and director of the Institute for Futures Research at the University of Stellenbosch, played a leading role, and Clem Sunter was also a participant. The broad purpose was to encourage strategic thinking about the future, and scenarios were seen as an essential input to this end. 
The work focused on such issues as the impacts, from economic and social development and community perspectives, of continuing with the then current allocation of resources between population groups, and the consequently adverse implications for political stability. While not directly addressed at the totality of apartheid and the underlying philosophy, the work clearly pointed to the fundamental untenability of the system.

Although never published - for fear of letting the government's opponents know that such thinking was going on - the output was widely disseminated within government. Not only were ministers exposed to it at the State Security Council, but an extensive programme of communication was implemented within the framework of the so-called Joint Management System which, through a central Council and sub-Councils across the country, brought together senior officials from all departments of government. There can thus be no doubt that when the Anglo American scenarios became public, there were a large number of individuals inside government who understood the consequences of the country's continuing on the 'low road'.

With respect to black and other opposition groups both inside and outside the country, little attention seems to have been paid to the scenarios. To the extent they were even known about at the time - I encountered general ignorance of them, even among the political and intellectual leadership - they were typically regarded as irrelevant, elitist, conservative, predictably neo-liberal and smacking of corporate self-interest, and also as not being effectively grounded in the real history of racial contestation in South Africa. They were, however, welcomed by some, because they could be taken to signal a weakening of the monolithic white power structure, which had hitherto been seen simplistically as an unholy alliance between the National Party government and the big corporate sector typified by Anglo American.

Finally in this section, and perhaps ironically, it seems that the scenarios had little impact inside Anglo American itself. They certainly did not influence corporate behaviour, except insofar as they helped some people recognise that they had to pay more attention to the global environment of their businesses, and the technique was not adopted for corporate planning purposes. It has in fact been only in the past few years that the scenario method has been taken up inside the group, interestingly with Clem Sunter himself playing a leading role as a facilitator on a consulting basis.

\section{Concluding comments}

Over and above the political impact noted above, there was a further contribution made by the Anglo project. This was to help establish the scenario method as an invaluable tool for analysing in the public domain complex 
problems in which vested interests are at stake. While scenario work had long been used in South Africa, including inside government as noted above, and while the Institute for Futures Research at Stellenbosch University had done pioneering work, ${ }^{7}$ the High Road/Low Road scenarios captured the imagination in corporate, professional and other circles to a degree that had not happened previously. To that extent they turned out to become a useful and perhaps even necessary platform on which the later Nedcor/Old Mutual and Mont Fleur exercises could build.

What were the principal characteristics of the Anglo project in terms of the concepts introduced in Chapter 2? It clearly started as a tool to facilitate strategic decision-taking by corporate management. But it shifted in its public dissemination phase into becoming a tool for advocating the need for change without, however, being prescriptive about the precise components of that change.

Finally, in its conduct the Anglo American project was essentially an expertbased project. A team of professionals, drawn from a range of disciplines rather than from diverse political or social perspectives, applied their minds to a hugely complex problem (and came up with ideas that found a wide currency, in good measure because of the style of their communication). The production of those ideas depended essentially on the intellectual input of the individuals and not on the need to accommodate radically different political philosophies or personal value systems among team members.

1 This section draws on Sparks (1990), Waldmeir (1997), Sampson (1999) and Landsberg (2004), as well as on interviews with Esterhuyse, F de Villiers, Gnodde and Spicer.

2 See Sunter (1987).

3 This section also draws on my interviews with Messrs Buys, Godsell, Ogilvie Thompson, Spicer and Sunter.

4 See Sunter (1996).

5 Interviews with Botha, Cronin, Davies, de Klerk, du Plessis, de Villiers, Erwin, Lee, Levett, Meyer, Malan Maphai, Maree, Mbeki, Morobe, Ogilvie Thompson, Roux, Spies, Stemmet, Tucker, Stals and van der Horst, and correspondence with Spies.

6 See Bond (2005).

7 See Spies (2004). 


\section{SOUTH AFRICA IN THE EARLY 1990s}

\section{The New Emphasis on the Economy}

\section{Introduction}

FW de Klerk's famous speech of 2 February 1990, inter alia unbanning the African National Congress (ANC) and other organisations and announcing the imminent and unconditional release of Nelson Mandela, set in motion a chain of events that led to the country's first fully democratic election on 27 April 1994 and to the formation of a Government of National Unity led by the ANC. The story of the protracted and on-off-on negotiations, violence, turbulence and uncertainty that accompanied this transition has been told many times ${ }^{1}$ and there is no need to repeat it in any detail here.

What must be said, however, is that the speech ushered in the unknown. While De Klerk evidently believed that his government would be able to control the transitional processes, which would in any event take many years, and also have a powerful influence on the outcomes, matters turned out rather differently. The reality was there were too many unknowns and unpredictabilities in the 'equation', and too many disparate and conflicting forces at work, for anyone to have been confident of the eventual results. And at various sticking points in the process there could be no confidence that the impasse would be broken and that the situation would not spiral out of control.

In a profound sense, everything in the society was 'up for grabs'. There was in principle no aspect of the country's polity and of the associated institutional arrangements that was not subject to scrutiny and to change. After all, a society that had been organised for over 300 years to serve the needs of a minority of 
the population at the expense of the majority now had the opportunity to design a different and more equitable future.

Moreover, this opportunity arose at a time of massive changes and uncertainties in the world order with the ending of the Cold War, the growing forces of globalisation, the continuing advances of the economies of East and South East Asia, the rising disquiet over the poor political and economic performance of Africa and many other factors. All this added to the complexity and the uncertainty facing South Africans in the wake of De Klerk's announcement.

It was in this climate that Nedcor and Old Mutual decided in May 1990 to mount a scenario exercise, which was undertaken in the period July-December of the same year. And, although matters had moved on, it was in essentially the same climate that the Mont Fleur scenarios were prepared in the period September 1991 to mid-1992.

Much of the story of the negotiated transfer of power, and certainly the aspect that has captured the popular imagination in South Africa and beyond, is focused on the politics. This is entirely understandable given the overriding need at the time to find a political dispensation that would robustly accommodate the conflicting interests of the various parties. It was politics, along with the associated contestation for power, that dominated the negotiations, and little thought was given to other factors.

Outside the negotiations, however, increasing attention was being paid to economic matters. There were vested interests, most obviously in the established business and financial sectors, as well as new voices arguing for radical changes in the approach to the economy in order to achieve more equitable distributions of income and wealth. In a nutshell, would the new government continue broadly on the neo-liberal path recently adopted by the National Party government? Or would it pursue a populist approach in order to meet the aspirations of the bulk of the population? Put simply, what would be the prevailing economic philosophy, notably with respect to the role of the state and to macroeconomic management?

If the High Road/Low Road scenarios can be characterised as having contributed to the need to search for a political settlement, then the Nedcor/Old Mutual and Mont Fleur projects must be understood as being relevant primarily to the embryonic economic debate. Even though they were both undertaken when the shape of the political settlement was still unclear - indeed, to emphasise what was said above, when it was far from certain that a settlement could be reached - their central focus was on the economy on the presumption that negotiations would be successfully concluded. And whereas the Anglo exercise as publicly disseminated was aimed at persuading the government of the time to enter into negotiations, the other two exercises came largely to be aimed at 
influencing the economic thinking of the as yet unknown though almost certainly ANC-dominated future government.

In order to set the context of these later scenarios, it is thus necessary to explore the evolution of economic thinking inside the ANC and its allies; for reasons that will become clear, this discussion covers the period up to 1996. This is the subject of the next section of this chapter, while analysis of the scenarios themselves will be dealt with separately in each of the following two chapters.

Before turning to the next section, however, it will be useful to touch briefly on the state of the economy at the time of De Klerk's speech and over the following few years.

\section{The South African economy in crisis}

The generally poor economic performance of the 1970s, apart from the 1979-81 gold-related boom, continued into the next decade, with declining income per head and rising unemployment. The imposition in the mid-1980s of sanctions from abroad, disinvestment by multinationals, calling-in of loans by foreign banks, the (illegal) export of capital by South African individuals and companies, maintenance of high levels of domestic protection which resulted in much of the manufacturing sector remaining deeply uncompetitive, growing concentration of ownership in the domestic sector, rising inflation, falling rates of fixed investment, continuing depreciation of the currency - all these and other factors pointed to an economy in crisis. The problems were compounded by the large and growing financial costs of maintaining apartheid, which resulted in uncontrolled and steadily rising public debt, not to mention the massive cumulative cost in human terms.

It was not until 1989, with the appointment of a new governor of the South African Reserve Bank and later with the election of FW de Klerk as State President, that the government started facing up both to the centrality of the economy to the political future of the country and to the harsh reality that the economy was in dire straits. That year saw for the first time the government embarking on the necessary measures to stabilise the macroeconomic situation. Over the next few years inflation was gradually reduced, though the balance of payments remained a serious constraint. Over the same period, partly but not only because of the forces released by the political transition, the fiscal position deteriorated further so that the budget deficit reached dangerously high levels. Overall, the economy remained in poor shape through the early 1990 s. 


\section{Evolution of economic thinking inside the ANC and its allies ${ }^{2,3}$}

The ANC's understandable and long-standing obsession with the removal of institutionalised racism as the foundation and the cornerstone of the South African polity meant that for a long time it paid less attention to other factors relevant to the country's future. Prominent among these, despite the ANC's deep concern about the race-based and huge disparities in wealth and in access to economic opportunity, was the economy. Indeed, the available evidence points to the party's having given little formal thought to economic policy until the second half of the 1980s. And while its allies, the Congress of South African Trade Unions (Cosatu) in particular, had made a dedicated effort starting in the mid-1980s to analyse the country's economic performance and problems, it was still a long way from articulating a coherent set of policies for the future.

To the outside world the ANC's economic philosophy had been set out in the 1955 Freedom Charter. The underpinning premise was that "the people shall share in the country's wealth", and the means to give effect to this included "transfer(ring) to the ownership of the people as a whole ... the mineral wealth beneath the soil, the banks and monopoly industry". These sentiments - entirely in line with Fabian thinking in post-war Britain and with the contemporaneous labour movements in continental Europe, as well as with the policies then being pursued by Nehru in India - were never articulated in detail, and no consideration appears to have been given as to how they would be translated into practice.

From the outset the ideas were ambiguous. The apparently obvious interpretation - that the ANC would nationalise the industries named - was the one that the party's critics and particularly the local and international business communities seized upon, and indeed nationalisation and ANC economic thinking became virtually synonymous in many people's minds. The fears of the West and of the country's business sector seemed to be realised when, in the speech made on his release from prison in 1990, Mandela affirmed the party's commitment to nationalisation.

There was an alternative interpretation, however. This was articulated by Mandela himself in an article written in 1956, which stated that the intention was "breaking up and democratis(ing) ... these monopolies... (to) open up fresh fields for the development of a prosperous, non-European bourgeois class (who) for the first time in the history of this country... will have the opportunity to own in their own names and right mills and factories... trade and private enterprise will boom as never before". ${ }^{4}$ In other words, that section of the Charter was what would today be regarded as an anti-trust, pro-competition statement aimed at breaking up monopolies and promoting new entrants. 
This ambiguity was both deliberate and necessary. It was not only because the issues had not been thought through, or that there was inevitably at the time a naiveté and an idealism about economic matters. It was rather because the ANC was, and remains, a broad church. The need was to find a form of words to which all of the diverse constituencies in the party could relate. The level of aspirational generality at which the Charter was expressed made this acceptable.

This ambiguity is key to understanding the evolution of the ANC's thinking, as well as its public statements, about the economy. The party's founders were principally professionals and intellectuals, educated locally and in some cases abroad within the paradigm of British liberalism, as well as influenced by leading black Americans, whose ambitions were uncomplicatedly those of an upwardly mobile professional and business class. They also included traditional leaders, Mandela himself being an example from a later generation, who fitted naturally into a hierarchical though consultative style of social organisation. In general, they were comfortable with the notion of a society based essentially on capitalism. Their virtually exclusive focus was on the political rights of black people.

As the movement evolved, driven by the overriding goal of defeating racism, the ANC came also to embrace a wide cross-section of society: rural peoples, workers in the agricultural, mining and manufacturing sectors, business people and others.

Some of these groups - notably the South African Communist Party (SACP), inspired by the Bolshevik revolution and provoked by the fierce capital-labour contestations that took place in the local mining industry in the $1920 \mathrm{~s}$ - brought into the debate Marxist analysis and prescriptions which emphasised the role of the state in planning and managing the economy. The attractions of socialism were obvious, given the history of exploitation on the part of monopoly capital in South Africa and the conditions of black workers in mining, agriculture and industry.

These leftist trends in the ANC were encouraged in the 1950s and 1960s by the optimism of the anti-colonial independence movements elsewhere in Africa, often with an aggressive socialist agenda, and by the writings of radicals such as Frantz Fanon. They were also reinforced by the fact of material assistance and moral support from the Soviet Union and Eastern Europe, which in part explains the growing influence of the SACP on the ANC in this period. Despite their different economic and political philosophies, a natural alliance developed between the ANC and the SACP, fuelled by their joint passion to bring down the apartheid regime. 


\section{The ANC after Sharpeville}

The banning of the ANC after the Sharpeville shootings in 1960 and the resulting growth of the organisation in exile further exposed some of its leadership to leftwing thinking internationally, whether of a radical student variety in Western Europe, of a social democratic nature as in Scandinavia or of a more dirigiste character as in the USSR and its allies. Nevertheless, the ANC's principal policy statement of this period - based on a conference held in Tanzania in 1969 - and a later document (1979) stopped short of an unequivocal commitment to socialism, a reflection again of the need to accommodate a wide set of perspectives.

In the 1980s increasing attention started being paid to the economy. Initially the principal individuals concerned were left-wing economists and other social scientists based at academic institutions mostly in the UK. The ANC, for which economic policy was not yet a priority, was not formally involved.

Within the country the legalisation of black trade unions in 1979 introduced powerful new forces on the political and economic scene in the 1980s. From the outset the unions' agenda went beyond traditional workplace concerns, and they readily found common cause with a number of left-wing academic economists who believed that the working class were the key to forcing political change in the country as a whole. (At the time some of these economists were opposed to the ANC, because they feared it would betray the working class. ${ }^{5}$ )

The first formal analyses of the economy by the left wing were initiated in 1986 by Cosatu, at the instigation of, among others, Alec Erwin and Jay Naidoo. The origins lay in the wish to argue that the country's deepening economic crisis was 'structural' in character and not the consequence of the sanctions then in place, and hence that the continuing imposition of sanctions could be supported. The work - undertaken by the Economic Trends Research Group (ET), a loose association of economists and other social scientists of left-wing persuasion, and funded from abroad - resulted not only in new insights into the causes of the country's economic malaise but also to early thinking about its prospects and future policies. ${ }^{6}$

Importantly, ET's output was the subject of high-level debates in 1988-89 in Cosatu and its affiliates. As a consequence, by the time of the ANC's unbanning in February 1990 Cosatu's leadership was well informed on the state of the economy, particularly in its sectoral, labour market and trade dimensions.

The SACP had always had strong views on the economy, though from an ideological rather than rigorously researched perspective. While there is some evidence that in the 1960s through the mid-1970s the SACP was the dominant intellectual partner in its association with the ANC, by the end of the 1980s this influence had diminished with the evident failure of communism in the Soviet 
Union and Eastern Europe. (Indeed the fall of the Berlin Wall in November 1989 marked a watershed not only for the SACP but also for many socialist-oriented economists such as members of ET.)

By contrast with Cosatu the ANC as an organisation was not well prepared. While in the mid-1980s it had set up what became the Department of Economic Policy (DEP), this undertook little if any formal economic analysis and its resources were distinctly limited. In the second half of the 1980s the ANC participated in a number of international conferences on the economy and continued to meet leading white South Africans from outside government. A particularly significant meeting was held in Lausanne in mid-1989, when ANC (and ANC-aligned), ET, government, business and academic economists discovered that they shared a great deal of common ground as South Africans, as well as in their analyses of the economy though not (yet) in their prescriptions. For many of these left-wing economists this meeting marked the start of a steep learning experience as they engaged for the first time with economists from government and more importantly from business - up to then they had essentially talked only among themselves.

\section{The ANC after 1990}

In early 1990 the ANC was a long way from articulating a coherent economic policy. This situation started to change quickly. The ANC and ET jointly organised a workshop in Harare in March/April 1990, resulting in a report entitled 'ANC and Cosatu Recommendations on Post-Apartheid Economic Policy'. This document, which was never formally endorsed, had as its starting premise the belief that the economy, "in fundamental crisis", had not been able to "meet the needs of the great mass of the country's people" and that the present strategies were "(un)likely to alleviate poverty and mass deprivation".

The envisaged remedies hinged on the new "democratic non-racial state ... (assuming) the leading role in the reconstruction of the economy in order to facilitate the realisation of its developmental objectives". A wide-ranging macro and micro policy agenda was articulated, much of it revolving around state intervention. At the same time the stance towards public finance was cautious, and initiatives to redistribute income and wealth "would pay regard to macroeconomic balance".

Nationalisation was regarded as "an essential part" of the reconstruction programme; not only would existing nationalised industries be retained, but the state would "be prepared as a matter of fundamental policy to renationalise privatised state assets ... (and to) set up new state corporations in areas where necessary". 
Although not fully articulated, the economic model implicit in these papers required a stable macroeconomic environment and a competitive internationally trading sector in order to deliver growth, with the state being responsible through the fiscus and public expenditure for redistribution of income in order to start addressing the legacy of deep and extensive social inequities.

Later in the same year the ANC's Department of Economic Policy (DEP) issued its own policy document, which was revised in 1991 and supplemented by further papers. This was broadly in line with the Harare paper, with the significant additions of the recognition of the vital role of the private sector in the economy and of the need for cooperative state-business relationships.

In addition to undertaking its own work, the ANC was subjected to many representations from outside parties, both national and international. Building on the meetings it had held in the late 1980s with the Mass Democratic Movement in South Africa and with the ANC in Harare, the Consultative Business Movement (CBM) convened a high-level conference 'Business and the ANC: Options for Building an Economic Future' in May 1990. The underlying purpose of the meeting was to signal that business accepted that change was inevitable and that it wanted to be a partner in designing that change. At this event, attended by the leadership of the ANC and its allies and of the business sector, Nelson Mandela and Gavin Relly of Anglo American made important statements about economic policy, with the former memorably assuring the audience that 'nationalisation' was not the only word in his party's economic vocabulary.

In the same year the World Economic Forum (WEF) started actively facilitating dialogue between local business and the ANC, and between the international financial and corporate communities and the ANC. Mr Mandela later paid warm tribute to the role of the WEF in this regard and even went so far as to say that South Africa would have turned out differently had it not been for the Forum. The Davos meetings in particular helped the ANC to understand the intensely competitive nature of international financial markets - on one occasion, after a presentation by the CEOs of several multinational corporations of their perspectives on global investment opportunities, Tito Mboweni was heard to remark with shock that none of them had mentioned Africa or any African country.

Bilateral interactions took place between the ANC/Cosatu, on the one hand, and, on the other, the World Bank and International Monetary Fund, foreign governments and businesses, international investment banks and others. Trevor Manuel was one of the small group who presented the Mont Fleur scenarios to the World Bank in Washington. The merchant bank Goldman Sachs hosted an extended visit to Washington and New York of senior individuals from the ANC's DEP; Tito Mboweni and Maria Ramos were among those who participated. 
The cumulative impact of such international exposure was significant. While the ANC and its partners knew they had to engage with local business leaders, and while at a personal level some of the relationships were warm, at that stage they never could bring themselves fully to trust the country's business sector, and far more credence was attached to the voice of the international financial and corporate communities.

Over this period the country's big companies, still led exclusively by white men, sought every opportunity to get to meet the ANC through private meetings, boardroom lunches and other means. In turn, the ANC's leadership reached out to the captains of industry; for example, at Nelson's Mandela's invitation, Harry Oppenheimer assembled a number of leading businessmen, known as the Brenthurst Group, for informal discussions with Mandela and his senior colleagues.

In May 1992 the ANC held a major conference, resulting in a statement of future policy intent entitled 'Ready to Govern'. The economic philosophy articulated in the document was based on an acceptance of the fact of globalisation and hence on the need to engage with the international worlds of trade and finance. The tone was one of outward-looking pragmatism and flexibility, accompanied by the need for proactive redistributive measures implemented through expenditure programmes. References to nationalisation were of such a nature as to make it a possible policy option rather than an ideological issue. Interestingly the earlier concept of 'growth through redistribution' was replaced by a separate formulation for each of these two terms.

At the Harare meeting of 1990 the idea had been mooted of setting up a new institution to underpin the ANC's economic policy work. Because of the microeconomic focus of the Industrial Strategy Project then being planned, the Macroeconomics Research Group (MERG) was established to work on monetary, fiscal and expenditure issues. The MERG team, which included a number of prominent left-wing British economists, proposed an inward-looking growth strategy and a willingness on the part of the state to run up large budget deficits. Significantly, the ANC's DEP (to which MERG reported) did not endorse the MERG report, and MERG's successor, the National Institute for Economic Policy, soon found itself at loggerheads with the ANC.

A formative influence on the economic policy landscape in the early-mid 1990s was the establishment in 1992 of the National Economic Forum (NEF). This came about as a result of Cosatu's insistence that it play a role in policy formulation, as well as of the recognition by Derek Keys, Minister of Finance and also of Economic Affairs, that it would be essential to the effectiveness of the De Klerk government in its final years to have a process through which government, organised labour and organised business could debate the full range of economic policy matters. While the NEF (and its successor NEDLAC) never 
achieved the status Cosatu sought but rather remained an advisory body, and in some respects little more than a talk-shop, it provided an invaluable meeting ground for the three constituencies to meet formally and to exchange views. For some of the participants, including even those as senior as the governor of the Reserve Bank, the Forum provided the first opportunity to engage with the other constituencies.

A recurring theme throughout this period, and a particular focus of the union movement and the MDM in general, was that the democratic order that replaced apartheid had to reflect the socio-economic hopes, and not only the political rights, of the mass of the people. There was in some quarters also a concern, as suggested before, that the ANC was not wholly committed to socioeconomic transformation. Accordingly Cosatu took the initiative in arguing that an ambitious approach to transformation was needed in order to meet the basic needs of the population - access to water and electricity, housing, health, education and the like - and in order to stimulate job creation. The resulting Reconstruction and Development Programme (RDP) was after much debate eventually adopted as the ANC's manifesto for the 1994 elections, and a revised version was published later that year as a government white paper.

\section{From the RDP to GEAR}

The RDP was clear on two critical matters.

First, there was a return to the earlier emphasis on redistribution and development (a wider concept than growth but dependent on it) and to the possibilities for a complementary and mutually reinforcing relationship between them.

Second, a fact often misunderstood or overlooked by some commentators at the time and subsequently is that the RDP was predicated on an orthodox approach to macroeconomic management. The specially created RDP Fund, managed by a new ministry within the Presidency, was set up explicitly within the constraints of fiscal discipline - the funds available to the RDP would come from a re-prioritisation of government expenditure and from a better use of existing resources, not from an increase in aggregate spending. Further, the RDP ministry made no formal input into any matters of macroeconomic policy. Several economic ministers were emphatic in public and private statements that, principally because inflation hurt the poor most severely, a conservative macroeconomic policy was a fundamental requirement. For essentially the same reason, Cosatu's leadership was supportive of this view.

For a variety of reasons the RDP as a formal programme was not successful, and in 1996 the ministry and the Fund were closed down. It would be wholly wrong to conclude that this meant the abandonment of the overall goals and the spirit 
of the RDP, which continue to this day to inform the government's socioeconomic philosophy and policies.

In the second half of 1995 concern started being felt in some quarters that the RDP alone would not be sufficient, within the prevailing macroeconomic framework, to raise the growth rate to a significantly higher level and to generate more employment opportunities. Work thus commenced on the formulation of a fresh growth strategy. As this proceeded, new factors entered the scene, notably a serious weakening of the currency in the first part of 1996 along with a sharp drop in foreign exchange reserves. A sense of economic crisis emerged, the first faced by the new government, exacerbated by a hostile remark about 'amorphous' markets made by Trevor Manuel shortly after his appointment as Minister of Finance in March 1996.

The upshot was a new policy document published in June 1996 by the Department of Finance, entitled Growth, Employment and Redistribution (GEAR). GEAR was controversial from the moment it was released and has remained so because of the government's insistence that it was non-negotiable even among its alliance partners and because, to its critics, it seemed like an unnecessarily self-imposed structural adjustment programme of the 'Washington consensus' variety.

GEAR confirmed the government's commitment to RDP-style policies and programmes at the micro level, as well as to continued opening-up of the economy to encourage international competitiveness. Its real impact, however, was at the macro level. It reflected an unequivocal belief in the necessity of macroeconomic austerity and of an outward-oriented economy for the country to be attractive to foreign direct investors in order to lift the growth rate materially (to six per cent per year by 2000) as well as the rate of job creation. Although these targets have yet to be met, the economic philosophy embodied in GEAR remains central to the ANC government's contemporary thinking.

The above discussion has explored the evolution of economic thinking inside the ANC and its allies from the time of the Freedom Charter (1955) to the mid1990 s when the ANC was firmly established in government. What it shows is a steady and logical progression from 'innocence' to a pragmatic grasp of what is required of a government responsible for an economy that is inextricably part of, and dependent on, the world economy but that also has the massive challenge of meeting the basic socio-economic needs of the bulk of its people.

\section{Reconciling the key constituencies}

In understanding how this happened, it is instructive to look at the key constituencies concerned. It was not just a matter of the ANC, Cosatu and the SACP. There was another dimension entirely, arising out of the need for 
reconciling, after February 1990, the views and aspirations of the returned exiles, the released Robben Island prisoners and the Mass Democratic Movement (MDM). None of these was a homogeneous group, but it is possible to venture generalisations about each:

- the exiles were generally highly sophisticated, well aware of the changing global geo-political picture and of the demanding requirements of international financial markets for a country to be an attractive destination for foreign investment. They included avowed communists, despite the collapse of the Soviet Union, as well as modernists and pragmatists who were only too aware of the failures of post-independence Africa and were therefore determined to show that a black government in South Africa could be thoroughly modern and internationally successful

- what is important to recognise in the Robben Island prisoners is that debates between the 'nationalists', who espoused a classically British liberal economic view of the world, and the 'socialists', who saw the world from a Marxist perspective, were never resolved. Perhaps this arose from their inevitable isolation from reality. But, inspired by the principled pragmatism of Nelson Mandela and his generous spirit of reconciliation, they were determined to find a robust and socially inclusive solution to the country's problems

- the MDM, whose membership critically included the unions, was potentially a force for populism. While its leadership became persuaded of the importance of fiscal discipline and correspondingly of the damage that would be caused to their own constituencies by a big-spending, populist approach, their passion was to redress the inequities of the past as a matter of urgency.

How were these disparate interests and associated views reconciled? Part of the answer lies in the fact that the many tensions and differences have never been wholly resolved. What one can say is that the ANC's leadership, firstly under Mandela and then under Mbeki, committed themselves unequivocally to being modernists and internationalists, as well as to running the economy in a disciplined and conservative manner. They understood that the latter was a precondition both for getting the economy onto a higher growth path and for making sustained impacts on the widespread poverty and on the deep damage wrought by apartheid. Their appointment of Derek Keys and Chris Liebenberg, both originally from the business sector, as successive Ministers of Finance in the first post-1994 government sent a clear message about their beliefs and intentions, and the subsequent style and policies of Trevor Manuel continued and reinforced the economic orthodoxy.

That these views prevailed did not mean, however, that other and contending views went away or remained silent. To a large extent the current battle for the 
new leadership of the ANC is precisely because significant elements of the ANC and its allies do not subscribe to such orthodoxy, and looking back one can identify a wide spectrum of views being expressed within the alliance at the same time as there was a dominant view.

It is interesting to observe that adherence to macroeconomic orthodoxy has not been accompanied by a corresponding conservatism with respect to the role of the state as an active player in the economy. While there has been a modest amount of privatisation, by and large the government's inclination has been to strengthen rather than to dismantle the existing state-owned enterprises. Indeed, because of the massive infrastructure investment programmes currently under way, several of these enterprises are now central to driving and underpinning long-term economic growth.

\section{Perceptions of the ANC's economic philosophy}

What the previous section has shown is that serious economic thinking inside the ANC, which began comparatively late, was subject to many different interest groups and pressures locally and internationally. Also, it evolved in a pragmatic fashion with widespread consultations within the party and its allies before key guiding principles were formulated and policy positions reached. What started emerging in the early 1990s was a recognisably modern framework for economic development, embracing a conservative stance on the macroeconomy along with growth and redistribution policies appropriate to South Africa's peculiar circumstances.

In this process sometimes radically conflicting perspectives had to be heard and, wherever possible, accommodated. The organisation's style was to encourage debate and typically not to impose still-contested views. This allowed opportunities for a variety of voices to be expressed, sometimes publicly. Such is the nature of the 'broad church' mentioned earlier.

How did the outside world see this process and the resulting products? The answer seems to be that most of it did not see them well and as a consequence did not properly understand them. As a result of the ANC's banning in 1960, there had been no opportunity for the local business community in particular to get to know the organisation and its leaders, and the nature of the colonial and later the apartheid governments had in any event been such as to separate physically and socially the black and white communities. Further, the banning in effect drove the ANC in exile into the arms of the Soviet Union and its allies, so that with the heightening of the Cold War it was possible for the South African government, backed by the USA and the UK in particular, to brand the ANC as a terrorist, anti-business and communist-inspired organisation. The continuing and sometimes very public membership of the SACP on a good number of the 
ANC's leadership bodies, including some holding responsibilities in the economic sphere, seemed to give substance to such assertions.

Of course, the increasing contact starting in the mid-1980s that first business and then government had with the ANC began to weaken the tendency to 'demonise' the latter, despite its close association with the SACP and Cosatu. But such interactions were insufficient to enable an informed understanding of the internal politics of the ANC and its allies, and consequently to remove the suspicion that, at least in the economic policy domain, the ANC alliance was likely to be radical and hostile to big business.

There was thus a general inclination to give credence to the views expressed by radical or minority groups, without recognising these for what they were and that they were unlikely to survive unscathed from the internal policy debates. There was a tendency to under-estimate the strength of the alliance and correspondingly to be unable to interpret intelligently the natural tensions within it. This could result in taking at face value policy statements that seemed provocative, but in fact had to be understood as part of intra-alliance jockeying. There was correspondingly a certain triumphalism in big business circles when Mandela, after the WEF meeting at Davos in 1992, signalled the need for the ANC to re-think its approach to nationalisation if it wished South Africa to be a competitive destination for foreign investment, and similarly when GEAR was announced in 1996.

1 See, for example, Waldmeir (1997), Bond (2004), Sparks (1994), Marais (2001) Friedman (1993) and Adam and Moodley (1993).

2 See Saunders and Southey (1998), Economic Trends Research Group (1990), Roussos (1990-91), Kentridge (1993), Gelb (1991), Gelb (1990-91), Gelb (1998), Kaplan (1990), Mbeki (2006), Hirsch (2005), Meredith (2005), Mohr (2003a, 2003b), Consultative Business Movement (1990), Sicre (2004) and Chapman and Wrightson (2004).

3 Interviews with Abedian, Cassim, Coleman, Cronin, F de Villiers, Eloff, Erwin, Esterhuyse, Friedman, Gelb, Gnodde, Gouws, Hirsch, Kaplan, Keys, Lewis, C Liebenberg, Makgetla, Mbeki, Mohr, Jay Naidoo, Jayendra Naidoo, Pahad, Roux, Schlemmer, Shubane, Sicre, Spicer and Van Zyl Slabbert.

4 Quoted in Mbeki (2006).

5 Several of these individuals went on to play important roles in the transitional processes of the 1990s and later in government and its agencies; among them were Alec Erwin, Alan Hirsch, Dave Lewis, Stephen Gelb and Dave Kaplan.

6 It led, too, to the formation of the Cosatu-backed Industrial Strategy Project, based at the University of Cape Town, which reported in 1995 on a strategy for the manufacturing sector. 


\section{The Nedcor/Old Mutual Scenarios}

\section{Origins and organisation of the scenarios ${ }^{1,2}$}

The prime mover behind the Nedcor/Old Mutual exercise was John Maree, who had been appointed chairman of Nedcor early in 1990 and who since 1985 had been executive chairman of the state electricity-generating company Eskom. He was at the time also a member of the board of Old Mutual (a major investor in Nedcor) and, through a variety of other past and present positions, well connected in both government and business circles. It was clear to Maree that FW de Klerk's unbanning of the ANC would usher in profound changes in the country at large, and that the business community would have to adjust to a very different world from the one they had known for many years.

Maree was intensely interested in what South Africa would look like over the coming years and, in the light of that, how he should position the bank in order to ensure that his legacy would be an enduring and favourable one. After consultation with Mike Levett, chairman of Old Mutual, the decision was taken in May 1990 for the two firms jointly to commission some kind of futures study. Arising out of a number of corporate and associated personnel changes, a senior executive Bob Tucker - who was known and respected by UDF leaders - was assigned to lead the exercise on a full-time basis. Tucker's judgment was that the scenario technique was ideally suited to what the two chairmen had in mind. Given that his instructions were to assemble the best possible team to undertake the work and, after consulting Clem Sunter of Anglo American, Tucker 
invited Pierre Wack to participate in order to draw on the latter's immense experience of scenario preparation, as well as on his international perspectives.

Tucker, assisted by independent consultant Robin Lee who served as the project's research coordinator, put together a top-class core team of 23 economists, political and social scientists, educationists, business people and others, while another 15 individuals of equivalent substance played specialist and/or advisory roles. Included among them were Willie Esterhuyse (facilitator of the government-ANC talks in Britain in the late 1980s), who was responsible for the political dimensions of the analysis, and Mamphela Ramphele (later to become vice-chancellor of the University of Cape Town and then a managing director of the World Bank), who led the work on the social dimensions. (See Annex $B$ for a list of the core team.)

The team's backgrounds included opposition movements, government and its agencies, the corporate and professional sector, the trade union movement, the World Bank, the NGO sector, academe and the media. Senior managers from Old Mutual and Nedcor participated as full members, and there were occasional presentations to overall management as the work progressed, but there was never any pressure on the team to produce a report acceptable to the two sponsoring firms.

Following interviews with some 40 top managers in the two sponsoring organisations in order to gauge their aspirations and fears for the future, the exercise proper commenced in July 1990. Guided by Wack, the approach was intensive - the core team met six times, typically for three-four days, always on a residential basis. After a full discussion of the scenario method at the first meeting, these sessions reviewed specially commissioned papers and also identified new areas for enquiry. Towards the end of the study phase of the project, two one-day meetings were held in order to give everybody the chance to make input into the final product. In addition to the formal sessions, many discussions took place in small groups to deal with specific issues.

The team's draft final report was presented to Maree and Levett in December 1990. They were highly impressed and also recognised that its scope and implications went far beyond the competence and authority of their two companies. Accordingly, they concluded that the work had to be widely disseminated, starting with the country's leadership across the full political spectrum and including leading players in the business and other communities. Presentations to the Cabinet, the ANC's national executive committee, the Inkatha Freedom Party, Cosatu and other key individuals and groups commenced in January 1991. A presentation was made to the World Bank in Washington DC. The team members involved in these presentations included Tucker, Wack, Mamphela Ramphele and Willie Esterhuyse. 
As word got out about the project, so requests were made for presentations to many other groups across the country. The decision was taken to respond positively to these requests at no cost to the audience, provided the host took responsibility for organising the event and accepted that only the full presentation - not an abridged or tailored version - would be available to them. (Since the full, and only, version could take up to seven hours to complete, the latter was no mean requirement - the implications of this, and the style of the presentation, will be discussed later.)

Dissemination of the work, which ran through 1991 into the middle of 1992, became a massive exercise in its own right. In addition to the team of five who made the early high-level presentations, a group of other individuals - several of whom had not been involved in the project - were trained to make the standard presentation in order to be able to respond to the many invitations. It is estimated that the aggregate audience numbered around 45000 South Africans. Tucker alone addressed some 250 meetings.

In addition to making videos of the presentations, the decision was taken to write up the full project and to publish it in book form. While a first draft was prepared in 1991, the book was not published until late 1992.

Altogether, the cost of the project was of the order of R5 million in the prices of the time, equivalent to about R17 million in 2006 prices. Probably some 60 percent of this went on the dissemination process.

\section{Methodology and content of the scenarios ${ }^{3}$}

The goals of the study were to:

- establish a basis for understanding South Africa in the 1990s and for developing appropriate business strategies

- provide a sound, well-researched basis for discussing the South African environment with other key players who had the capacity to influence that environment.

While, unlike the Anglo American exercise, the main focus of the work was on South Africa rather than the global economy, the team devoted considerable effort to understanding the international experience of transitions from authoritarian rule. They reached two key conclusions which informed their subsequent thinking, viz:

- a successful political transition involved far more than simply a transfer of power. By successful they meant "a stable democracy, based on a stable social fabric with rising incomes which are reasonably distributed"

- since South Africa was starting from a position of secular decline in the economy, widespread poverty, steeply skewed income distribution and 
rising violence, alongside a fixed commitment to change the political system, there was an overriding need for economic and social transformation if democratisation was to be sustained. Indeed, the need was urgent and had to be met before the transition to democracy, not after.

The second of these conclusions was reinforced by the analyses, some of them pioneering, undertaken of the South African political, economic and social contexts. This work highlighted, in ways that had seldom been seen before, the depth and extent of the country's problems, as well as the inter-connectedness of social, economic and political factors.

The same conclusion was further underpinned by the assessment of the outlook for the economy over the period 1991-95. This work, based on analysis of the country's performance within the framework of the international economy and using sophisticated modelling techniques, showed that, if South Africa continued on its prevailing economic path and even under favourable assumptions about the relevant parameters, only modest growth (at most three percent a year) would be achieved. This growth would be barely sufficient to achieve increases in average income per head, let alone to generate the resources needed to tackle the vast social backlog.

These findings led to a further key conclusion. This was that there had to be what they termed a 'change of gears' not only in economic policy but also in the social and political spheres, resulting in an integrated growth and development strategy. 'Business as usual' in all three dimensions was simply not an option.

Accordingly the team constructed a 'change of gears' scenario premised on three separate but interdependent changes:

- a shift in economic strategy from one that was inward-looking and resourcebased to one that was outward-looking and manufacturing-driven

- a shift in resource allocation in order to finance producer-oriented social investment for the black population

- a move from a culture of top-down decision-making to one of consultation involving all sections of the community, based on area- and problemspecific compacts between the players concerned.

The team went on to formulate specific proposals for realisation of this scenario. Notable among these were ambitious proposals for increased spending on inter alia low-cost housing, electrification, education and healthcare (aimed chiefly at HIV/AIDS), along with creation of a job corps. Consistent with Pierre Wack's approach to scenario work, detailed thought was not given as to how these new programmes would be implemented. Critical assessment was made, however, of the economic, social and political impacts of the scenario if it were to be implemented. The team concluded that not only was a 'change of gears' 
essential, but that its impacts would have to be felt by 1995 at the latest, which was then seen as the likely date for a political settlement. They thus believed that a window of 18 months existed (up to mid-1992) for this up-side scenario to commence being implemented.

The project echoed the sentiment in the Anglo American exercise that a successful transition, or otherwise, was not pre-ordained. It was up to South Africans themselves to bring about that success.

The final chapter of the book explored the implications of the team's findings for the country's future. It related the work to that of the Anglo American project and in particular concluded that the 'change of gears' constituted an essential means of getting onto the 'high road'. It also argued that, by not pursuing this scenario, the country would inevitably find itself on the 'low road'.

Interestingly, in this last chapter attention is drawn to the team's identification of a previously unrecognised contradiction in the project sponsors' implicit view of the future: "On the one hand, they had a favourable scenario which hypothesised a stable coalition government with a market-oriented policy of redistribution through growth. On the other hand, they were subscribing to a widely-held business view that we could carry on with 'business as usual' during the transition". The contradiction, which lay in the argument that 'business as usual' would not result in the required growth, sprang from the uncritical assumption that the economic, social and political dimensions of transitions were separable, and in particular that the outcome of the political negotiations then just getting under way were independent of their socio-economic context.

As indicated, Maree and Levett were delighted with the team's work, though Maree in particular felt that more specificity was needed especially in respect of strategies for economic growth, employment generation and education. Accordingly Nedcor and Old Mutual sponsored a further project in which a specially assembled 'Professional Economic Panel', coordinated by Robin Lee, formulated 22 wide-ranging proposals to these and other ends. The Panel's report, entitled Growing Together: institutions and initiatives for economic democracy and growth, was published in February 1993 and then in revised form a year later. The Panel's work, despite the high calibre of the participants who came from a diverse set of constituencies, is not widely remembered today. Nevertheless, two of its proposals - independence of the Reserve Bank and establishment of a fiscal commission on government spending and its financing - did in fact come about, though it must be recognised that these ideas had a wider currency and it is unlikely that the Panel's views were decisive. 


\section{Impact of the exercise 4}

Of the scenario projects covered in this review, the Nedcor/Old Mutual exercise was by a margin the most comprehensively and empirically researched. The range of its enquiry was impressive, as was the rigour and the imagination brought to its analysis of South Africa's deep-seated economic and social problems, much of which remains apposite today.

For the sponsoring companies, and indeed for the business sector generally, the study provided fresh insights into the economy, not least because its view of economic performance was without qualification so unfavourable. What the team said - and they did not mince their words - came as a revelation to this sector, where the prevailing wisdom was that the South African economy was powerful and competitive, even though they produced no findings that were not known to the Economic Trends group, some parts of government and independent analysts. The impact of what they said was all the greater, because their arguments had originated in an exercise sponsored by business itself.

The reasons for this impact are not hard to find. Protected over many years by tariffs, excessive concentration of ownership and the freedom to exploit labour, South African business had been able to maintain its profitability; cut off from international best practice because of sanctions, business was typically unaware of just how uncompetitive it was; and associated with these factors was a high standard of living for the (white) business community. Not surprisingly there was a degree of complacency in the sector, along with a tendency to think that, if their own firms were doing well, that automatically meant that the whole economy was in good shape.

For the business community, and to some extent the government, the project broke new ground too in its integrated treatment of economic, social and political issues. The Anglo American project had shown the importance of the political economy rather than only of the economy, but it was conducted at an abstract level, and it was essentially silent on social and developmental issues. The Nedcor/Old Mutual exercise, by contrast, was located not only in South Africa's particular transitional circumstances, relative to international experience, but also within the complexity and massiveness of the social challenges it faced. It was for some audiences a 'revelation' to understand the significance, indeed the centrality, of these societal dimensions.

Intellectually, therefore, the Nedcor/Old Mutual project represented a significant advance in analysing the country's problems. There was, and remains, a view among members of the core team that it was one of the most intellectually stimulating exercises they had ever been involved in. All whom I interviewed had clearly found it mentally invigorating and stretching, and had themselves learnt much. Even though, with hindsight (arguably also at the time), some of 
the reasoning can be seen to have been flawed, the project as reflected in the book and the videos was an honest and professional contribution by a group of people whose individual and collective bona fides could not be faulted.

What, though, was its wider impact? There is of course, as with the High Road/Low Road exercise, not a single or simple answer to this question.

My overall impression, however, is that its impact beyond the team itself was modest:

- in the Cabinet, despite the credibility of the project derived from John Maree's personal standing and from its unquestioned intellectual substance, there was in general a sense that change was already under way and that the $a$-political and overly-prescriptive approach was inappropriate. There was also scepticism about the feasibility of the 'change of gears' scenario

- in the business community the unequivocally harsh criticism of the state of the economy was, for all its validity, a tough message to swallow. For many, it was an unacceptable message. However, some of those who did listen found the message sobering and also had their eyes opened for the first time to the interrelationships between the economy, society and politics, though not all were persuaded that a 'change of gears' was really necessary

- in Nedcor and Old Mutual there was and remains pride in having sponsored the exercise. But there is no evidence that its findings and arguments were deeply thought about beyond a small number of individuals or that the two companies went about their respective businesses differently, including their planning methods, as a consequence of it. As in the case of Anglo American, there was only a modest change in the mindset of top management derived from a greater confidence about the future and wanting to be part of it. (There is evidence, however, of an impact on the thinking and practice inside Eskom)

- in the ANC, Cosatu and opposition movements there was a mixture of responses. From a political perspective the exercise was seen as selfinterested pleading on the part of big business, even if welcomed as an indication that there were some in the business community capable and willing to engage in fresh and ambitious thinking. From an intellectual and policy perspective there was a connection between, on the one hand, the high priority attached to social investment in the 'change of gears' scenario and, on the other, the RDP - the authors of the latter were directly influenced by the Nedcor/Old Mutual report. In some quarters there was appreciation of the fact that the extensive public communication effort made by the Nedcor/Old Mutual team provided the first opportunity for many individuals to meet and interact in any serious way with the business sector. In other quarters resentment was expressed about the social analysis, which was regarded as altogether too pessimistic 
- more generally, the work was regarded respectfully but perhaps also fearfully because of the complex and daunting picture painted. This was perhaps not unhelpful among conservative white communities, because nothing had prepared them for the changes that De Klerk had unleashed and this project exposed them for the first time to the huge challenges that lay ahead.

Why was this so? In a nutshell, the answer lay in how the project was disseminated. This was essentially a matter of style and tone. There was a tendency to lecture rather than to engage, along with an implied sense that, having done the research, the team were uniquely placed to know all the answers. There was an almost evangelical tone, which did not always go down well.

The tone also included a tendency to use technocratic language and a reluctance to allow too much interaction with the audience. These factors, along with the many hours insisted upon for the presentation, imposed a burden on the audiences. Even if impressed with parts of the analysis and perhaps the prescription, the audiences found themselves struggling to comprehend the totality and also felt that they had been at the receiving end of a barrage of words; these reactions were less marked in small meetings, where the opportunity for questions and answers was greater. In contrast to the High Road/Low Road, people did not come away from presentations feeling hopeful and stimulated and also that they had been entertained.

\section{Concluding comments}

Although undertaken as a classic scenario exercise, the resulting videos and report South Africa: Prospects for a Successful Transition comes across more like a conventional piece of public policy analysis. The viewer/reader is presented not with a number of different possible futures but rather with the conclusion that, to avoid the 'low road' and to have a chance of getting onto the 'high road', South Africa has no option but to embark on an integrated economic, social and political strategy, the main elements of which are spelled out. As such, the project's most obvious characteristic, with reference to the concepts introduced in Chapter 2, is its use as an advocacy tool.

It is interesting to reflect on Pierre Wack's posture in this regard. As observed in Chapter 2, he came to hold strong views on whatever topic he worked on, based on deep thought and research conducted with ruthless logic and balanced rigour. He believed that the scenario thinker had to present the work in such a way that it not only stimulated the thinking of the audience, but also persuaded them of the robustness of the scenarios and the validity of the underlying reasoning, even if were up to the audience as to how to use the scenarios. 
It was thus entirely consistent with Wack's philosophy - especially bearing in mind the critical circumstances facing South Africa at the time, in which 'business as usual' offered a disastrous prospect and therefore a 'change of gears' was essential - that the team's report was used for advocacy purposes.

From an independent vantage point some 17 years later, however, my sense is that the decision to go so emphatically along the advocacy route was probably counter-productive. It put audiences on the defensive, it did not do proper justice to the high quality of the analytical work undertaken and it did not leverage the power of the scenario method to full advantage. The problem was compounded by the wide scope of the analysis, which took many in the audiences into unfamiliar terrain, and the use of language that was hard for the layman to follow. It is interesting to speculate whether the impact would have been greater if the style and tone chosen for disseminating the scenarios had been infused with hope.

Finally, the working method in the Nedcor/Old Mutual project, like Anglo American's, essentially involved individuals making expert inputs. These were then analysed by the core team, who went on to assess the implications and to formulate a report which integrated the principal findings, conclusions and recommendations. Although the composition of the team was deliberately drawn from a wide range of social and political perspectives, there was not a conscious effort to design and implement a process of facilitating exposure and then reconciliation of the different perspectives among team members. This was very much a 'content' or 'expert-based' exercise.

1 See Tucker and Scott (1992).

2 Interviews with Maree, Levett, C Liebenberg, Tucker, van Niekerk, van der Horst, Porter and Lee.

3 Interviews with Esterhuyse, Gouws, Lee, Levett, Maree, Ramphele, Schlemmer, Tucker and Van Zyl Slabbert.

4 Interviews with De Klerk, D de Villiers, du Plessis, Erwin, Esterhuyse, Friedman, Gelb, Gouws, Hirsch, Lee, Levett, C Liebenberg, Makgetla, Malan, Maree, Mbeki, Morobe, Jay Naidoo, Jayendra Naidoo, Ramphele, Schlemmer, Spies, Stals, Tucker, van der Horst, van Niekerk and Van Zyl Slabbert. 


\section{The Mont Fleur Scenarios}

\section{Origins and organisation of the scenarios 1,2}

The Mont Fleur scenarios - named after the venue in the mountains outside Stellenbosch where the team met - differed from the other two projects in several significant respects. It was a project essentially of civil society and emphatically not the corporate sector; it was from the outset well connected politically with the ANC in particular; it adopted a methodology dependent on facilitating debate and finding common ground among diverse perspectives, rather than being research-based; and it had a modest budget. Nevertheless, as will be seen, it came to exercise an influence not only in South Africa but internationally.

The project came about as follows. In mid-1991 Pieter le Roux, a development economist and director of the Institute for Social Development at the University of the Western Cape (UWC), was approached by the Friedrich Ebert Stiftung to organise a conference on South Africa's economic future. Le Roux, who had convened the meeting in Lausanne in mid-1989 referred to in Chapter 4 and who was active in the post-apartheid economic debate, was sympathetic to the social democratic principles that the Stiftung wanted to advance, but was not convinced that yet another conference would make a useful contribution to South Africa at that juncture. After consulting various people, including at least one who had been involved in the Nedcor/Old Mutual project, he persuaded the prospective funder that the project should take the form of a scenario exercise in which the participants would be from the left. 
Le Roux's express purpose was to seek to influence the economic thinking of the country's future leadership. A liberal Afrikaner from a conservative background, he had studied abroad and had first-hand insight into the Scandinavian economies. His 'agenda' was to encourage a policy commitment to the market along with proactive measures for redistribution. Beyond this, he had no specific ideas as to how a scenario exercise would turn out.

Because of the scepticism with which scenario work was regarded by the academic community, including himself, Le Roux made a special effort to understand the scenario method. This included travelling to London to meet Adam Kahane, who at the time was head of social, political, economic and technological scenarios in Shell's planning department, and to invite him to serve as facilitator of the proposed project. Kahane had visited South Africa on Shell business and was keen to get involved. Shell agreed to allow him to do so, contributing his time at no charge.

Le Roux now set about assembling the team, bearing in mind Kahane's recommendation that a spread of perspectives was essential - both the process and the final product would be diminished if only left-wing views were articulated and so 'awkward sods' also had to be in the room. He did this in association with Vincent Maphai, a political scientist also at UWC. Maphai and Le Roux shared a number of characteristics: highly regarded across the political spectrum for the independence and integrity of their professional work and their views, while not aligned to any party in particular, and well networked. Apart from seeking to involve individuals from political and other groupings on the left, plus a few from the business world, they looked for (mostly) young people who they felt would come to play significant roles in shaping the country's future. They expressly sought out individuals whom they regarded as bright, flexible and open-minded, capable of debating in mutually respectful and impersonal style, who clearly were committed to addressing the challenges facing the country.

Further, they took the precaution of consulting the ANC, through Thabo Mbeki, to make sure both that the party was informed about and comfortable with the project and also that the ANC members invited to join the team - Trevor Manuel, Tito Mboweni and Saki Macozoma in particular - were acceptable choices. The Pan African Congress's leadership was correspondingly consulted (as was Archbishop Desmond Tutu), but not that of other political parties. The SACP had one participant. A rather half-hearted and unsuccessful attempt was made to get the Inkatha Freedom Party to participate; the absence of Inkatha was later much regretted. Cosatu were approached but, because the project was low on their list of priorities, did not feel they could justify the involvement of any of their leading individuals. They also did not feel comfortable being involved in a process in which their 'representative' could operate only in an unmandated manner. Nevertheless, one of the team members did have a strong 
union background and his participation did have the endorsement of Cosatu's general secretary, Jay Naidoo.

The final team of 22 included academics, business people, party political officials and others. With the exception of three business people and an 'establishment' but open-minded economist, there was a pronounced though not necessarily radical left-wing bias. The team was multi-disciplinary, with economics being the dominant discipline. (See Annex C for a list of the team.)

Funding - in the order of R200 000 in 1991 prices (about R580 000 in 2006 prices) - was from the Friedrich Ebert Stiftung and the Swiss Development Agency, with support in kind from Shell. The project was managed out of Pieter le Roux's Institute at UWC.

The first meeting was held over a week-end in September 1991, and two further such meetings took place at the end of that year and in March 1992. The work between meetings principally consisted of the members testing the emerging ideas among themselves and in due course with their respective constituencies, though in addition a number of papers on underlying economic and social trends were prepared. Some inputs came from members' own research interests, of which perhaps the most important was a review of the Latin American experience of economic populism in the 1970s and 1980s.

At the last meeting, in August 1992, at which not all members were present, the team's final report was presented to politicians from parties that had not participated - the ruling National Party, the Democratic Party and the Conservative Party - as well as to leading individuals from other sectors. Formal presentations were then made to the national executive committees of the ANC and PAC, the National Party, government departments, industry associations and individual companies, trade unions and other organisations. Subject to the availability of an appropriate team member, requests for presentations were responded to positively, with profit-making organisations being asked to pay a small fee to help cover costs. In addition, a pamphlet was printed for insertion into The Weekly Mail \& The Guardian Weekly, which had a circulation of some 30 000 , and an entertaining video, animated by the political cartoonist Zapiro, was produced.

\section{Methodology and content ${ }^{24,25}$}

When Adam Kahane arrived in South Africa in 1991 to start the Mont Fleur project, he had, because of pressures of other work, done uncomfortably little preparation by way of background reading on the country's complex transition, on the participants and so on. But he had enough basic understanding, reinforced by his gentle and listening manner, to be credible to the team. More importantly, he knew that he knew only a little. It was clear to him that his role 
was to ensure the integrity of the process and, complementarily, the willingness of the assembled participants to take responsibility for the content.

The method he applied was unusual. On the first evening, after the formal introductions, he asked the team to start thinking about the country's possible future. Each individual was asked to articulate one or more 'stories' about how he or she thought the future might unfold over the next decade, and expressly not what he/she wanted to happen. Over that week-end 30 such stories emerged. They were subjected to scrutiny - for the realism of their assumptions, their logic, their feasibility and so on - and were reduced to nine that were deemed worthy of further study. Under Kahane's guidance, such interrogation was conducted throughout in a personally non-threatening way, so that the author of any particular story did not necessarily feel embarrassed when his or her story was judged to be implausible. Four sub-teams were then tasked to explore these nine possible scenarios in their political, economic, social and international dimensions.

The second workshop in December 1991 looked critically at the nine scenarios and eventually reduced them to four. The choice was determined by three questions: whether the political negotiations would result in a settlement; what the duration and pace of the transition would be; and how sustainable the new government's economic policies would be. These three questions in effect constituted branching points, thereby resulting in four scenarios.

At the third workshop the selected scenarios were reviewed and refined, and plans were made for their dissemination. The team also agreed to take collective responsibility for all four of the scenarios, which was important in that it meant that all members, irrespective of their own views and/or political affiliations, could not dissociate themselves from any one of them.

In between these meetings background research was undertaken, including the use of the UNISA economic model to look at possible growth paths. In addition, Le Roux and Maphai spent time with individual team members to talk through the different scenarios in order not only to refine them but also to ensure that everybody was comfortable with them.

Also at the third meeting the earlier thinking was confirmed that the dissemination style be light in touch and free of jargon to ensure ready and wide accessibility. It was agreed that images associated with birds would be used to capture the essential messages of the scenarios; some were chosen then and at least one was suggested later by an outsider.

The first scenario was the Ostrich, in which despite the promising start the existing government puts its head in the sand and refuses to make meaningful concessions to the opposition. Negotiations break down, mass resistance is repressed and the earlier history of a deteriorating economy, social 
disintegration and political violence is repeated. Eventually negotiations are resumed, but in even worse circumstances than before.

The second scenario was the Lame Duck. Here the negotiations result in a transitional arrangement that is so hedged about with sunset clauses and other checks and balances, in order to meet the fears of the different groups, that the government is severely incapacitated and massive uncertainty prevails. This leads to a loss in business confidence, and the vicious cycle of decline resumes. By the end of the period, an arrangement that was intended to appeal to all satisfies none.

Icarus was the title of the third scenario. It was named after the mythical Greek figure who, exhilarated by his ability to fly using feathers stuck together with wax, flew too close to the sun with the result that the wax melted and he plunged into the sea. The message here was about the dangers of macroeconomic populism: a popularly elected government goes on a social spending spree accompanied by price and exchange controls and other measures in order to ensure success. For a while this yields positive results, but before long budgetary and balance of payments constraints start biting and inflation, currency depreciation and other adverse factors emerge. The ensuing crisis eventually results in a return to authoritarianism, with the intended beneficiaries of the programme landing up worse off than before. ${ }^{3}$

Whereas the first three scenarios were negative, describing futures to be avoided, the fourth sketched a more optimistic and even bright future. Entitled Flight of the Flamingoes, its imagery is that of a large number of birds that take a good while to get air-borne but eventually do so and fly together steadily and purposefully in the same direction. What it conveys is a successful transition - a favourable outcome to the constitutional negotiations followed by a democratically elected government which, while observing macroeconomic constraints, adopts progressive social and other policies, resulting over time in significantly improved economic performance and a gradual rise in the living standards of all.

\section{Impact of the scenarios ${ }^{4,5}$}

There were at the time many and varied reactions to the scenarios. At one level there was a tendency to rubbish them as being intellectually slight, and to criticise them because of their failure to confront the socio-economic legacy of apartheid. At another they were well regarded as substantial, as cleverly capturing the then current political uncertainties and economic realities, and also as illuminating the fundamental choices facing the country. At a third, because of the simple and readily understandable language used, as well as the humour of the cartoon images, they had an easy appeal. 
What was significant about the scenarios was where they originated and who was involved.

That an exercise coming from the left should produce Ostrich and Lame Duck scenarios may not have been surprising, but Icarus would not have readily been expected. Among conservative sections of society, notably in business circles, the credibility of the whole project was considerably enhanced because of the honesty with which the team had reached its conclusions about the dangers of economic populism. Similarly, while dismissed by some as a flight of fancy, Flight of the Flamingoes suggested a mature government committed to long-term economic and social development, but aware of the constraints arising out of the realities of the international economy.

The composition of the team turned out to be critical, as was the decision that presentations to the left-wing political parties should be made by individuals from the team who were members of the particular party concerned. To have a member of the ANC, SACP and the PAC make a presentation to his/her respective party, which included a warning about the counter-productive consequences of economic populism, undoubtedly had a powerful even if controversial impact on that party.

The significance of the make-up of the team can be gauged by looking at the subsequent careers of five members who were ANC officials or ANC-aligned at the time of the work, viz Trevor Manuel, Tito Mboweni, Sue van der Merwe, Rob Davies and Saki Macozoma. All five became MPs after the first democratic election, with Manuel becoming Minister of Trade and Industry in 1994 and Minister of Finance in 1996, Mboweni Minister of Labour in 1994 and Governor of the Reserve Bank in 1999, Van der Merwe Deputy Minister of Foreign Affairs in 2004, Davies Deputy Minister of Trade and Industry in 2004, and Macozoma, having left Parliament in 1999, chief executive of Transnet and later deputy chairman of Standard Bank.

Clearly all five have been influential, but Manuel (who had been a leading member of the UDF in the 1980s) and Mboweni (a trained economist, who had been in exile) stand out because of the central roles they played in development of the ANC's economic thinking. At the time of Mont Fleur they were both in the ANC's Department of Economic Policy, where they were involved in projects such as MERG, and over the next few years before entering government they were intensively exposed locally and internationally to a wide range of economic, financial and business perspectives.

The question arises: given these many influences, what impact, if any, did Mont Fleur have on their thinking? In Manuel's case the answer is unequivocal. In an unpublished interview in $\mathbf{2 0 0 0}$ he said "it is not a straight line (from Mont Fleur to GEAR). It meanders through, but there is a fair amount in all of that going back to Mont Fleur that we were able to draw on ... (While) if we try and attribute 
every ... (influence on economic policy) ... to Mont Fleur ... we won't make it stand, (nevertheless) ... by virtue of remembering those scenarios, I could close my eyes and could give them ... just like this. I've internalised them, and if you have internalised (something) then you probably carry it for life. I can still visualise the way we took the discussion on macroeconomic policies in a breakaway group. I can replay that tape over and over and over in my head." ${ }^{\prime 6}$

The evidence with respect to Mboweni is only indirect. In that same interview Manuel, in remarking that he was not the only one who had 'internalised' the scenarios, referred to the fact that at the dinner marking his inauguration as Reserve Bank governor Mboweni had reassured the audience that he was not an Icarus. Further, several of the Mont Fleur team whom I interviewed said that they had no doubt that the project had helped shape Mboweni's thinking, as indeed they felt of Manuel too.

It would be wrong to focus attention only on these two individuals. With only one exception, all of the 11 participants whom I interviewed recalled their pride and pleasure at having been involved, of the unexpected friendships they had made and of the fresh insights they had gained into the South African scene. Even the academics amongst them, despite their natural suspicion of 'process', retain rich memories of the whole experience and are now inherently more respectful of the intellectual challenge of designing and executing 'process' as part of achieving a useful outcome.

The further question thus arises: how did a project that was only modestly research-based or empirical come to exercise any impact on these individuals, bearing in mind the many other influences on them? The answer lies in a combination of separate but mutually reinforcing factors - timing, venue, process, simplicity and team composition.

The timing was critical. The country was going through a period of huge uncertainties and as a consequence there was in some quarters, typified by the Mont Fleur participants, a willingness to explore new approaches and to think outside the box. They were driven by a shared passion both that the country should succeed and that they individually and collectively could influence the outcomes.

The venue was 'perfect'. A residential conference centre set in beautiful surroundings, where they were for the period the only occupants, Mont Fleur offered a relaxed facility where during breaks the participants could walk in the mountains, play billiards or other games or just chat among themselves. Echoing the efficient and unobtrusive style of the project's administration, the centre's staff was dedicated to ensuring that everything worked smoothly. Given that not too long before this South Africa's apartheid rules had made it very difficult if not impossible for such a mixed group to interact socially and even 
professionally, there was an intensity in the experience which reinforced the sense of excitement that the group was embarking on something rather special.

The distinctive feature of the process was the quality of the facilitation. The unanimous and unequivocal view of my interviewees was that Adam Kahane's role was fundamental to the success of the project. His cerebral, subtle and listening style ensured that space was given to every view expressed, as well as to any counter-arguments. While this occasionally irritated some of the participants, who felt he was almost obsessed with process to the detriment of content, they all came to see the wisdom of an approach that ensured inclusiveness and that positively sought to accommodate different perspectives. At the same time, however, he did not allow 'fudging'. There were times when some team members felt the discussion was leading nowhere, but Kahane invariably managed to steer it into fruitful directions and to bring it to closure. His ability to combine a laid-back and a profoundly serious approach worked well, as did the fact that he started off knowing so little about South Africa.

The evident success of the process is all the more remarkable given the limited research and empirical base. The reasons for this lie not only in Kahane's style of facilitation, but also in the problem-solving spirit in which the project had been set up, the willingness with which the team members had made time available so that they could participate and the quality of the individuals themselves. The challenge to them was to draw deeply on their personal, professional and other experience in order to compensate for the lack of a formally structured intellectual foundation - while with hindsight one can see important gaps in their work, such as the virtual silence on the socio-economic implications of HIV/AIDS - there is no doubt about the intellectual gravitas of the scenarios, despite their being so simply expressed verbally and so wittily portrayed pictorially.

The impact of the scenarios owed much to their simplicity. The content of each was readily understandable to the layman, and this was reinforced by the uncomplicated style of presentation in all its forms (personal, video and written).

Finally, there is the matter of the make-up of the team. This has been remarked on before, because of the inspired selection made principally by Le Roux and Maphai. What characterised the team was not only its leadership qualities evident in the team members' subsequent careers - but also the passionate commitment, intellectual substance and generous spirit of the individuals involved. Despite the deliberate left-wing bias in its composition, the team displayed integrity in facing up to where their assumptions and rational debate led them and they did not flinch from reaching conclusions that were not necessarily palatable personally or to their constituencies.

Moreover, the individual members gelled together well as a group. While at the start there was nobody who did not know at least one other person and, in a few 
cases, several people, many of the members were new to one another. They enjoyed 'finding' one another as fellow South Africans, and clearly found the whole exercise not only intellectually and personally challenging but also fun. Those whom I interviewed recalled the experience with pleasure, highlighting the friendships made (sometimes 'for life') and particular incidents that were especially meaningful in their own development or simply humorous.

One particular episode points to the significance of having in the team individuals who were already well networked and destined to play national roles in the imminent future. At the presentation of the scenarios to selected Cabinet ministers and others in August 1992, one of those present was Derek Keys. Formerly chief executive of a large mining and industrial group, he had been brought into the Cabinet by FW de Klerk as Minister of Economic Affairs in January of that year and in May took on the Finance portfolio as well. As chair of the Cabinet sub-committee dealing with all matters pertaining to the economy with the expenditure and revenue sides of the budget, and with the President focused on the political transition, Keys exercised huge influence. Moreover, he was already known personally to some of the ANC officials involved in the scenario project (as he was to other opposition leaders, notably in Cosatu), and there was a high degree of mutual respect and trust.

Keys fitted in well with the spirit and informal style of the Mont Fleur team, arriving in a modest car and dressed casually (in contrast to most of the other invitees). Moreover, after the presentations and discussion, when virtually all of the guests had departed to watch an international rugby match in Cape Town, Keys elected to stay with the team and watch the game on television. At the end of the match Keys casually mentioned that he happened to have in his car slides of a presentation he had recently made to Cabinet on the state of the economy and asked whether the team might have any interest in seeing them. This duly happened.

It was, in Keys's distinctive style, a 'minimalist' presentation with simple charts and limited accompanying commentary. But the effect was devastating. South Africa's economic performance, absolutely and also relative to selected countries, was clearly seen to be extremely poor across a wide range of indicators. The team was shocked, and Trevor Manuel (who was known to have a special relationship with Nelson Mandela) was heard to remark that he would urgently convey to the ANC's leadership what he had just learnt.

There is an interesting postscript to this story. In mid-September 1992, only a few weeks after this episode and at a time when political negotiations had broken down, a wide-ranging interview with Mandela was published in Johannesburg's leading daily newspaper The Star. Mandela made the following comments on the economy: "We want to break the deadlock (in the negotiations), because if we don't, I fear that the economy is going to be so 
destroyed that when a democratic government comes into power, it will no longer be able to solve it. The longer it takes for democracy to be introduced, the more difficult it will be to repair the economy.

"I have always known this to be the case, but on Friday I got a briefing from Trevor Manuel after he met Derek Keys. He brought a statement from Keys which is well-considered, and spells out in detail the actual state of our economy. And I got frightened. Before Trevor had finished I said to him: 'Now what does this mean as far as negotiations are concerned?' Because it appears to me that if we allow the (deadlock) to continue, we are going to face the prospect that even when we have introduced a democratic system and are able to organise resources from abroad, it will still be very difficult to repair our economy."

This episode and its aftermath are not so much about the significance of Mont Fleur - after all, it was not a question of the impact made by the scenarios - but rather about the value of having in the process individuals of high standing who could engage on an equal footing with individuals in power and who could convey messages swiftly and authoritatively to the top of their own constituencies. In this respect Mont Fleur can be seen as an important node in a set of networks in which individuals such as Trevor Manuel participated, and the output of which will have influenced interactions with the individuals' other networks.

There is also an interesting link, through this story, to the Nedcor/Old Mutual project. Shortly after becoming Minister of Finance, Keys used to be briefed on the state of the economy by Rudolf Gouws of Rand Merchant Bank, who had played a leading role in the economic analysis (though not the prescription) undertaken in the Nedcor/Old Mutual exercise. On one chance occasion Keys was particularly impressed by Gouws's perspectives and, having received hard copy of the analysis, used this as the basis for the presentation that he gave to the Mont Fleur team.

To conclude this section: there is no question but that Mont Fleur, because of the combination of factors identified above, had a real impact on the thinking first and foremost on its participants. And, because of who those participants were, there was a knock-on impact on their respective constituencies and, further, on the evolving economic policies of the ANC-led Government of National Unity and then of the subsequent government. These impacts must, of course, not be exaggerated, because of all the other things happening at the time and subsequently, as recounted in Chapter 4 . But this does not make them any the less real or meaningful.

There is some evidence that it was not only the ANC that was influenced. The PAC, 'represented' by Mosebyane Malatsi, following a presentation led by him of the scenarios, engaged with Kahane and Le Roux and subsequently retracted 
their (the PAC's) negative stance towards participation in the 1994 election. The evidence also suggests that they were forced to re-think their generally populist approach to the economy.

Beyond this, in South Africa there was limited direct impact. While a number of businesses and business organisations had presentations made to them interestingly, Trevor Manuel and Tito Mboweni being their preferred presenters - there was not a wide awareness of the exercise and, perhaps because it was so different from the earlier corporate-sponsored projects, not much attention or credence given to its output. Much the same can be said of the conservative political parties.

Internationally, however, through the way Kahane's career subsequently evolved, Mont Fleur has achieved distinctive standing. In a nutshell, Kahane was able to build on the Mont Fleur methodology to pioneer new approaches both to conflict resolution in some of the world's most troubled countries and regions, and also to addressing complex societal problems. Partly because of support from the United Nations Development Programme (UNDP), as well as comparative research sponsored by them, Mont Fleur has attained almost iconic status internationally as a futures project that contributed to a country's proactively getting itself onto the 'high road'.

\section{SA2020: An attempt to 'repeat' Mont Fleur',}

In 2003-04 another scenario project took place at Mont Fleur. It was the brainchild of London-based Peter Wilson, executive director of the African Leadership Institute, and of John Ohiorhenuan, then the UNDP's resident representative and UN coordinator in South Africa, and it had the support of Brian O'Connell, vice-chancellor of the University of the Western Cape and a member of the original Mont Fleur team. The UNDP sponsored the project.

In addition to O'Connell, Sue van der Merwe, Pieter le Roux (still at UWC) and Saki Macozoma of the first Mont Fleur project were involved at the beginning, but either withdrew or remained on the sidelines. A number of other prominent South Africans played advisory roles or made specialist inputs.

Twenty-three young South Africans, drawn from a "broad spectrum of ideas, philosophies and backgrounds", plus six young leaders from elsewhere in Africa, were the participants, and Wilson himself was the principal facilitator. The team met over a period of 10 months in five plenary and sub-group workshops. The project, known as SA2020, generated four scenarios about how South Africa might look in 2020:

- Dead End, which explored the possible outcome of self-serving leadership, uncurtailed corruption and rampant individualism 
- Sharp Right Turn, which examined the implications of a South Africa focusing only on achieving high economic growth

- Slow Puncture, which investigated the possible outcome of South Africa's choosing to beat the same path rather than adopting a bold vision and decisive leadership to reduce inequalities

- All Aboard the Dual Carriageway, which examined how South Africa as a country could challenge its approach to growth and development and choose a bold path that would enable all to climb aboard the dual carriageway to a better life.

The team produced a booklet and a DVD and, although the original intentions had been ambitious, there were only two public presentations of the material.

Despite the project's apparent 'pedigree', very few people knew of it at the time of its execution and even now very few people know of its output. Although one of its purposes was leadership development of the participants - which may have been achieved for some - the principal objective was to take stock of where South Africa stood ten years after the original Mont Fleur project and to chart ways forward for the future which would contribute meaningfully to public debate. The evidence is that it did not meet this goal. Why was this so?

The answers seem to lie in a nexus of factors which made the project the very antithesis of the original exercise.

First, it was not soundly established politically - worse, it encountered hostility in high places. The UNDP had, unusually for a UN agency and despite all the normal protocol, recently published a report that was critical of South Africa's achievements in the socio-economic domain. The South African government was thus not well disposed to a UNDP-sponsored project about the future of the country, and the politicians and several others connected with the exercise never gave it their wholehearted backing. As a consequence, the UNDP withdrew its financial support, which is why the dissemination effort was so modest.

Second, the timing was not propitious. In 1991-92 South Africa was at a watershed and its forward-looking leading citizens were passionate about engaging with the big issues that would shape the country's future. There was a real sense of carpe diem and of personally and collectively being able to make a difference. A decade later the atmosphere was rather different. The ANC government was firmly established and, because of problems being encountered with respect to its policies towards HIV/AIDS and Zimbabwe in particular, tended to be defensive rather than receptive to new ideas that came from outside. Besides, the post-1994 freeing-up of the media and other vehicles for public discourse, including the freedom to meet and debate with anybody 
across the full spectrum of opinion, meant that there was no longer the novelty that attended the Mont Fleur interactions.

Third, notwithstanding the outstanding individuals amongst them, the quality of the participants, in terms of their potential to make a big impact at national level, was simply not in the same league as that of the earlier exercise. Whereas Le Roux and Maphai, given their standing and their networks, had been superbly placed to assemble a team of exceptional individuals, as outsiders neither Wilson nor Ohiorhenuan had the credibility or the insights to make equivalent choices.

Fourth, the extraordinary 'chemistry' that had generated the original team's enthusiasm for their project did not happen in the second exercise. In the first, the participants positively looked forward to the next workshop; in the second, such an attitude seems to have been the exception rather than the rule.

Fifth, management of the project proved problematic. This stemmed in part from the lack of congruency in the aims of the project's sponsors and organisers. It also resulted from weak administration - team members were not kept well informed about what was happening, and to this day some of them have not received the report and the DVD that was produced (and in at least one case were unaware of their existence).

Finally, the style of facilitation was not conducive to the high degree of openness that had characterised Mont Fleur. The debate also often got hijacked by individuals with strong personal agendas, and the balance and calm logic despite the passion - of the original exercise never prevailed.

\section{Concluding comments}

Mont Fleur and SA2020 respectively provide instructive examples of how to, and how not to, undertake scenario work at the national level, if the intention is to influence public debate and to contribute to shaping the future of society. The next chapter will, drawing also on the Anglo American and Nedcor/Old Mutual projects, seek to draw out the general lessons that emerge from South Africa's unusual experience of scenario work in the domain of the political economy.

The Mont Fleur project's predominant characteristic, within the framework presented in Chapter 2, is clearly that of raising awareness and building consensus. Although it could be argued that it also contained an element of advocacy, my sense is that the four scenarios were presented neutrally without the suggestion of preference or probability of outcome. That having been said, clearly only one of the four depicted a desirable outcome, and so to an extent there was something of an implicit 'high road'/'low road' choice. 
By contrast, SA2020 turned out to be an exercise in intellectual enquiry only. Some but not all of the participants benefited in terms of their personal development but, because of the project's political 'isolation' and to some extent its naiveté, its wider impact was zero.

Mont Fleur, unlike the Anglo American and Nedcor/Old Mutual projects, depended principally on 'process' and on accommodating diverse stakeholder perspectives. There was intellectual content, of course, introduced through participants' particular expertise and experience, through some research and through a few specialist inputs.

But essentially it was an exercise in reconciling the diverse personal philosophies and perspectives of the participants, along with their aspirations and fears for the wider society. As such, its methodology was quite different from that of the other projects. Despite its modest research base, Mont Fleur had a profound impact on individual members and also generated scenarios that offered serious insights into the dilemmas and choices then facing the country. There is food for thought here for anybody contemplating scenario work in a complex environment.

1 See The Weekly Mail \& The Guardian Weekly (1992), Kahane (1993) and Kahane 2004.

2 Interviews with Boesak, Kahane, P le Roux and Maphai.

3 An interesting analysis of the dangers of economic populism, based on the Latin American experience, is given in Mohr (1994), who was a member of the Mont Fleur team.

4 Interviews with Davies, De Klerk, D de Villiers, Erwin, Esterhuyse, Gouws, Kahane, Keys, $P$ le Roux, M le Roux, C Liebenberg, J Liebenberg, Malan, Maphai, Morobe, Mohr, Jay Naidoo, Jayendra Naidoo, O'Connell, Spicer, Spies, Stals and Taylor.

5 See Pruitt (2004) and Gillespie (2000).

6 Transcriptions of the interviews with 14 members (including Trevor Manuel) of the Mont Fleur team, used in Gillespie (2000), were made available to me through Adam Kahane.

7 See UNDP, African Leadership Institute and University of the Western Cape (2004).

8 Interviews with Klein, P le Roux, O'Connell, Bodibe, Taljaard, Van der Merwe and Wilson. 


\section{SCENARIOS AND THE POLITICAL ECONOMY}

Preceding chapters have shown how three very different scenario projects impacted to a greater or lesser extent on South Africa's political economy, as well as how a fourth made no impact whatsoever. What conclusions can be drawn from this varied experience? There are seven main points to be made.

The first is by way of prefatory comment. Every scenario exercise is unique, with its own purposes, structures, cast of characters and the like. While there may in principle be a 'correct' way of undertaking a project, in practice the methodology adopted is unique to each. This is because 'process' and 'content' are not mutually exclusive and can never be entirely separated. Also, because of the personally interactive nature of the process, the individuals involved make inputs not just through their expertise and special insights, but also through their different philosophies and styles which impact on the dynamics and the path of the process.

What emerges strongly from the contrast between, on the one hand, the Anglo American and Nedcor/Old Mutual projects and, on the other, Mont Fleur, is the question of balance between 'process' and 'content'.

Some of the people I interviewed insisted that a scenario was worthless unless it was based on rigorous research aimed at identifying the 'drivers' of change and also the key environmental uncertainties and risks. Their arguments were that relying only on the participants' personal experience would inevitably lead to omission of factors they found 'uncomfortable' or were simply outside their ken, and also that there was no 'reality check' on their inputs and conclusions. Their presumption was that a research-based project would not suffer from similar or other problems. 
I question this. In the first instance, for all the rigorous intellectual input into both the High Road/Low Road and Nedcor/Old Mutual projects, one can admittedly with hindsight - readily see how many things they got 'wrong'. To cite but one example from each.

In the former, the international analysis was predicated on the three main economic actors in the 1990s, viz the USA, Japan and the Soviet Union - clearly the team did not foresee the diminished role, for different reasons, that would come to be played by the latter two countries.

In the latter project a central argument was that economic and social transformation had to be achieved if political transformation was to be sustained, and that a window of some 18 months was all the time that the country had in which to achieve this. Given the country's deep-seated human development and other socio-economic problems - areas in which the team in fact undertook outstanding work - which international experience suggested would take generations to solve, such a time-frame was never going to be realistic. Besides, even if the National Party government of the day had been persuaded urgently to address the socio-economic issues, they would not have had the expertise or the credibility, not least among the intended beneficiaries, to mount anything of consequence.

In the second instance, despite its limited analytical rigour and empiricism, Mont Fleur unquestionably generated fresh and substantial insights into how the political economy could evolve and similarly it shaped the thinking of its participants. And while one can argue that the resulting scenarios suffered from critical gaps and/or from being somewhat basic - for example, there was no exploration of how as damaged and fragmented a society as South Africa could in a matter of only a few years take off and start flying smoothly and in unison the evidence points strongly to Mont Fleur's having made an invaluable contribution to the development of the political economy of macroeconomic thinking in particular.

In the third instance, it is readily evident that the Mont Fleur process was such that it added value to the understanding on the part of the participants of the world they lived in, and over which some of them would come to exercise authority. For all its apparent slightness in academic terms, Mont Fleur had real substance.

The second point, which follows from the first, is that part of the attraction of the scenario method is precisely its potential to combine in a rigorous manner the intellectual and the experiential approaches to public policy. Achieving this will never be easy, because there is something inherently different in the 'culture' of an analytical exercise compared with one dependent on generating what might be termed 'real-time' inputs from participants in the course of the project. The fundamental keys to success lie in the skills of the facilitator and in 
having around the table high-calibre individuals whose perspectives 'represent' the diversity of the society's principal constituencies.

Third, the power of the technique lies in its inherent capacity to look dispassionately at issues and options and to allow logic and commonsense, rather than predetermined premises and conclusions, to explore the answers. This, done transparently and honestly, results in a non-confrontational process in which the participants have the space, intellectual and emotional, to change their views without losing face. Again, much depends on the quality of the participants and of the facilitator.

Fourth, irrespective of the approach adopted, if an exercise is to make a useful contribution, it must have legitimacy among the groups it is targeting. It is interesting to consider the above four projects from this perspective:

- in a sense High Road/Low Road initially had no legitimacy beyond Anglo American which, after all, commissioned it for internal planning purposes. What external legitimacy it came to acquire was essentially earned as a result of the international dimensions of the work and also, to emphasise what was said in Chapter 3, the challenging but non-threatening and problem-solving style of its formulation of the South African problem. Also, it came at a time when the country's political leadership and the white business establishment were increasingly responsive to fresh thinking in order to prevent continuing deterioration in the country's circumstances and eventually violent conflict

- the Nedcor/Old Mutual project, also commissioned partly for internal purposes, had some legitimacy in government circles principally because of John Maree's standing and connections, though in the event this does not seem to have been decisive. The project also consciously sought wider validity through the make-up of the team, and it achieved standing because of the quality and also the innovativeness of its work. But, for the reasons suggested in Chapter 5 and despite the bona fides of the team, it was never quite able to get recognition much beyond the white business sector

- Mont Fleur, by design, had legitimacy in the parties of the left, which gave it the opportunity to be influential in the government of the future. It acquired, through the honesty with which it faced up to the economic realities of the new South Africa, legitimacy in other quarters ${ }^{1}$

- SA2020 never had legitimacy. Apart from the tension at the time between the UNDP as project sponsor and the government, the fact that the exercise was designed and put together by outsiders who were not particularly well networked in South Africa inevitably weakened its standing.

Fifth, the style of public dissemination of scenarios is crucial to their impact. This is powerfully illustrated in a positive sense by the Anglo American exercise, and in a negative sense by the Nedcor/Old Mutual project. (Mont Fleur's impact 
depended in only small part on its external dissemination.) There is no need to repeat here what has been said in earlier chapters about what made for effective communication of the first of these projects and for ineffective communication of the second.

Two points are worth making, however. The first is that the impact is dependent on the simplicity, clarity and 'memorability' of the message. The High Road/Low Road scenarios said in essence that South Africa could choose to go for success or to be doomed for failure - this rather than the international dimensions of the exercise is what lodged in people's minds and indeed is still remembered. Analogously, the message for which Mont Fleur is best remembered was that a populist economic path was unsustainable and would lead to trouble.

The second point is that any programme of wide public dissemination is necessarily very costly. Even if video and now DVD technology open up new and apparently cheaper possibilities, in terms of impact they are clearly inferior to personal presentations, provided these allow for a high degree of interaction with the audience.

Sixth, the three projects on which this study is focused are linked. The Anglo American exercise popularised the scenario method and built the intellectual foundation on which Nedcor/Old Mutual was able to build. Both in turn, perhaps particularly the latter, prompted the 'scenarios of the left' initiative which resulted in Mont Fleur. If the first had not been undertaken, one may speculate that neither would the second nor the third. It was as if a progressive legitimisation of the technique occurred, which helped create a 'culture' in the country of scenario work. This in turn helps explain why and how the three projects came to exercise some influence and also why the scenario method remains current in the country. For instance, essentially for internal governmental purposes the Presidency carried out a scenario project in 2004 entitled Memories of the Future: South African Scenarios 2014, and it is at present well advanced on a fresh exercise. These are over and above the public-domain issue-based projects listed in Annex D and the numerous projects that have been carried out over the years in the private and parastatal sectors.

Finally, the biggest question of all: would South Africa now be a different place if the High Road/Low Road, Nedcor/Old Mutual and Mont Fleur exercises had not taken place? This is an impossible question to answer definitively. Besides, one could ask the question of numerous other initiatives and processes over the past 20 years.

Despite these qualifications, my clear sense is that in their different ways each helped break the then prevailing paradigm and consequently made a difference. Their impacts were not evenly spread, but were nevertheless real. Societal change is brought about by many factors, sometimes simultaneously and 
sometimes not, and the scenario projects studied here must be seen as catalytic rather than causal factors in this process.

1 It is fascinating to speculate what additional impacts Mont Fleur might have had if it had focused as incisively and robustly on the social challenges facing the country as it did on the macroeconomy. Given, in the subsequent years, the deterioration in the health and education sectors, the rise in violent crime and other problematic trends, one can only regret this omission. Perhaps it would have been too much to expect a single team to have grappled simultaneously with macro/economic and micro/social issues. But even if the Mont Fleur project had simply pointed to the need for urgent work in the latter areas, and if a new team had then been assembled which included future leaders in them, one can imagine that the ambivalent thinking and ineffective delivery currently evident in many areas of social policy might have been avoided. 


\section{DESIGN AND EXECUTION OF PUBLIC-DOMAIN SCENARIOS}

\section{Some Pointers}

\section{Introduction}

The core objective of this study, as set out in Chapter 1, is to offer guidelines for the planning and conduct of future scenario studies undertaken in the public domain. That the lessons are drawn from a study of major scenario projects carried out in a fascinating and critical period in South Africa's history, which has an interest in its own right, does not deflect from that central purpose.

There is a certain irony in drawing conclusions about public-domain scenarios when two of the cases studied started as corporate scenario projects. 
Nevertheless, despite their originally different motivations, they - along with the other case studies - offer useful pointers for future projects.

The previous chapter argued that every scenario exercise is sui generis. This implies that there are no universally valid rules as to how to set up and carry out a new project. The most that can be done is to identify the factors that need to be borne in mind and where possible to offer general guidelines as to how they might be addressed. The next section deals with these matters.

There is a cascading and inter-linked logic in the formulation. The overriding requirement is to be clear about the strategic objectives of the exercise, which then inform in an interrelated way all the other dimensions.

The material on which this chapter is based is drawn only partly from the review of the scenario studies reported above; it also derives from my own experience over many years of involvement in public policy work.

Finally in this introductory section, what can be said about costs? This study has shown just how expensive the research work and the process of public dissemination can be (vide the Anglo American and Nedcor/Old Mutual projects), as well as how substantial impacts can be made with only modest resources available (Mont Fleur). There is clearly not a single or simple answer, and one can say little more than in designing any new project careful thought is required from the beginning as to how use the available resources.

\section{Key issues and guidelines}

\section{First and foremost is clarity of purpose:}

- why is the project being undertaken?

- what are its intended outcomes?

- whom is it intended to influence?

- if there is more than one target audience, will different 'products' be required?

- is it clear that the scenario technique is the most appropriate methodology?

- is the exercise one of advocacy or of consensus-building, or both?

Is the timing right?

- is there sufficient recognition, in the target audience(s), of the problem being addressed and therefore of the potential benefit of the proposed project?

- is there enough instability in the political environment and/or contextual uncertainty and risk, so that the project participants will want to think outside the box, and the audiences and wider stakeholders will respond to fresh thinking? 
What will give the project legitimacy in the eyes of the target audience(s) and in the broader stakeholder community?

- who should be involved in financing and promoting the project? It is critical that, if there is more than one party involved, there should be total congruence of purpose

- are special governance arrangements needed, e.g. an independent steering committee or advisory body? In general, simplicity in governance structure should be the guiding philosophy, and special arrangements should be avoided where possible, provided the independence and integrity of the project are not compromised

- which are the constituencies whose participation in the team is a precondition for its legitimacy, and how should their 'representatives' be selected? The temptation can too easily be to go for comprehensive inclusiveness, which could result in an unmanageably large team

- which are the constituencies with whom consultation at critical stages will be sufficient? What form should such consultation take? Especially if some important voices do not have a place on the team, because numbers have to be limited, a special effort must be made to ensure full consultation before the team's conclusions are finalised

- are special measures needed to ensure the political connectedness and integrity of the project, so that its bona fides cannot be questioned and its process and output are above question?

What qualities are required of the facilitator?

- first of all, is a facilitator needed? If the project is an exercise in advocacy, the answer may well be no. If it is about consensus-building where there are diverse views present, the emphatic answer is yes

- if the latter, the essential characteristics are independence, neutrality, the ability to listen and to give space to fresh perspectives, acceptance of responsibility for the integrity of process and a sense of fun. Knowledge of the subject matter should not be a requirement, though it should not rule people out.

Who should drive the design and organisation of the project?

- the only general comment to be offered is that the individual(s) concerned must have real credibility not only with the sponsors but with all the other stakeholders.

How should the project be administered?

- simply, efficiently, unobtrusively and in friendly fashion.

What should be the size and composition of the team? 
- Having too large a core team, no matter the argument for representativeness, is likely to be counter-productive. Once the number gets much above 20, the opportunity for focused and coherent debate becomes limited and the process becomes unmanageable. (This does not gainsay the possibility of involving many more individuals, such as through formal consultations in both the research and the dissemination phases, and through the commissioning of specialist inputs)

- the composition must reflect the stakeholder interests concerned, as well as the special expertise required and perhaps also independent perspectives. There are many considerations to bear in mind, eg interest group, age, gender, geographic origin, race, subject knowledge and the like, and the answer will depend on the mix of characteristics available in each of the eligible candidates. There must be not too much like-mindedness - this would defeat the object of the exercise - though it is important that all participants subscribe to the overall purposes and the values of the project

- where target groups can be identified in advance, they should be represented in order both to ensure their viewpoints are adequately accommodated and to facilitate communication of the project's output to their respective constituencies

- the fundamental requirement is to involve individuals of exceptional quality - of real intellectual substance and honesty, principled but pragmatic, willing to debate and to listen to and, where appropriate, to accommodate other perspectives, committed to solving the societal problems being addressed, all in all people who are passionate about making a difference

- what other criteria should be borne in mind? The individuals chosen should be 'known' entities, in that there are no total surprises as to how participants behave and what views they espouse. And sufficient numbers should from the outset commit to being available to participate in the dissemination phase, so that a few individuals are not over-loaded and/or there does not have to be recourse to the use of outsiders

- as an aside, ensure that the opportunity and the environment exist for the participants to get to know one another informally from the start of the exercise.

What methodology should be adopted?

- the more the intention to build consensus among divergent perspectives, the greater the emphasis on a process-based exercise

- conversely, the greater the intention to be an instrument for advocacy, the greater the need for an empirical and research-based project

- the balance between the two approaches, which are not mutually exclusive, will always be a matter of judgment

- the choice of methodology will profoundly influence the choice of the facilitator. 
What should be the duration of the exercise and of the workshops?

- the shorter and the more intense the whole exercise, the better. Too protracted a process, along with too much time between meetings, runs the risk of not generating the momentum essential to bring focus and decisive conclusions

- but these considerations must be balanced against the need to allow enough time between meetings so that participants can reflect on the discussions and explore their implications before meeting again as a group

- similarly, the duration and structure of group meetings during the project must allow the combination of intense mutual engagement and personal reflection in an environment that is insulated from outside pressures - two nights and two or three whole days at a venue where there are no other parties present would seem to be about right.

How should the scenarios be disseminated?

- the lesson from this study is unequivocal: simply and in language comprehensible to lay people (including politicians!), non-threateningly, non-prescriptively and always with a light touch

- present to smaller rather than larger groups

- allow more rather than less time for questions and answers. The method chosen should, within budgetary limitations, allow for reaching as wide an audience as possible.

\section{Concluding comments}

This study has shown the potential contribution of the scenario method at the level of the political economy, in the extreme case of a society, firstly needing to commit itself to transition and secondly to negotiating its route through transition. It also shows how many factors have to be borne in mind if that contribution is to be realised. If these factors are systematically identified and addressed, subject to the quality of the work, there is a chance that the project will have an impact on the course of public events; if they are not addressed, the probability is that the only beneficiaries will be the participants themselves.

The study has also shown the many other dynamics underway before, during and after each of the scenario projects studied, that reinforced the scenarios' messages and were reinforced by them, or which facilitated the receptivity or otherwise of what the scenarios were saying. As remarked earlier, (successful) scenario projects are better seen as catalytic rather than causal factors producing societal change - if appropriately executed, they can certainly be useful and may even be necessary, but they can never be sufficient. The South 
African experience unequivocally demonstrates the positive contribution that scenario work can make.

1 In parentheses, as it were, it might be observed that the uncertainties over the presidential succession both of the ANC and the government, and consequently over the economic and other policies that the post-2009 government will pursue, combined with the crises in health, education and other sectors, suggest that the time is ripe in South Africa for a fresh set of scenarios. These would need to be generated through asking a series of what/if questions depending on the qualities of the new leader(s), on the future of the ANC/Cosatu/SACP alliance and other factors. At the same time it must be recognised that South Africa, well into its second decade of transition, is an infinitely more complex place than it was in the early 1990s, with many more 'voices', many more agendas and far less unity of purpose. Mounting a successful scenario exercise in these circumstances will consequently be greatly more challenging. 


\section{BIBLIOGRAPHY}

Adam, Heribert and Kagila Moodley, The Negotiated Revolution: Society and Politics in Post-Apartheid South Africa, University of California Press, Berkeley and London, 1993.

Bishop, Peter, Andy Hines and Terry Collins, "The current state of scenario development: an overview of techniques", Foresight 9(1) 2007.

Bond, Patrick, Elite Transition: From Apartheid to Neoliberalism in South Africa, University of Kwazulu-Natal Press, Scottsville, 2005.

Chapman, Neal and Peter Wrightson, "Civil Society: The role of business and the churches in facilitating the transition", in World Economic Forum, 2004.

Consultative Business Movement, Business and the ANC: Options for Building an Economic Future, Proceedings of the Carlton Conference, Johannesburg, 1990.

Economic Trends Research Group, “Recommendations on Post-Apartheid Economic Policy", ANC-Cosatu workshop, Harare April-May 1990, published in Transformation 12, 1990.

Galer, Graham, "Scenarios of Change in South Africa", The Round Table 93 No 375, 2004.

Friedman, Steven (ed), The Long Journey: South Africa's quest for a negotiated revolution, Ravan Press, Johannesburg, 1993.

Gelb, Stephen (ed), South Africa's Economic Crisis, David Philip Publishers, Cape Town, 1991.

Gelb, Stephen, "Democratising economic growth: Crisis and growth models for the future", The Investment Analysts Journal 33, Johannesburg, 1990-91.

Gelb, Stephen, "The Politics of Macroeconomic Policy Reform in South Africa", Paper presented to the Conference on Democracy and the Political Economy of Reform, Cape Town, 1998. 
Gillespie, Glennifer, The Footprints of Mont Fleur, in Pruitt, 2000.

Hirsch, Alan, Season of Hope: Economic Reform under Mandela and Mbeki, University of Kwazulu-Natal Press, Durban, 2005.

Kahane, Adam, "Learning from Mont Fleur: Scenarios as a tool for discovering common ground", Deeper News 7(1), Global Business Network, 1993.

Kahane, Adam, Solving Tough Problems: An Open Way of Talking, Listening, and Creating New Realities, Berrett-Koehler Publishers, San Francisco, 2004.

Kaplan, David, "Recommendations on Post-Apartheid Economic Policy - Comments", Transformation 12, 1990.

Kentridge, Matthew, Turning the Tanker: The Economic Debate in South Africa, Centre for Policy Studies Research Report 32, Johannesburg, 1993.

Landsberg, Christopher, The Quiet Diplomacy of Liberation: International Politics and South Africa's Transition, Jacana, Johannesburg, 2004.

Marais, Hein, South Africa: Limits to Change - the political economy of transition, UCT Press, Cape Town, 2001.

Mbeki, Moeletsi, Concepts of transformation and the social structure of South Africa, Public lecture delivered at the University of the Witwatersrand, 26 April 2006.

Meredith, Martin, The State of Africa: A History of Fifty Years of Independence, Jonathan Ball Publishers, Johannesburg, 2005.

Mohr, Philip, "Can South Africa avoid macroeconomic populism?", Development Southern Africa 11(1), February. 1994.

Mohr, Philip, "An overview of the South African economy in the 1990s", South African Journal of Economic History 18, September 2003 a.

Mohr, Philip, "The South African balance of payments in the 1990s" South African Journal of Economic History 18, September 2003b.

Pruitt, Bettye (ed), Proceedings of the UNDP Civic Scenario/Civic Dialogue Workshop, Guatemala, November 2000.

Roussos, Mike, "The place of nationalisation in the economic policy of the ANC", The Investment Analysts Journal 33, Johannesburg, 1990-91.

Sampson, Anthony, Mandela: The Authorised Biography, HarperCollins, London, 1999.

Saunders, Christopher and Nicholas Southey, A Dictionary of South African History, David Philip Publishers, Cape Town, 1998.

Schwartz, Peter, The Art of the Long View: Planning for the Future in an Uncertain World, Doubleday, New York, 1991.

Shell International, Scenarios: An Explorer's Guide, London, 2003.

Sicre, Frédéric, "Introduction" in World Economic Forum, 2004. 
Sparks, Allister, The Mind of South Africa: The Story of the Rise and Fall of Apartheid, Heinemann, London, 1990.

Sparks, Allister, Tomorrow is Another Country: The Inside Story of South Africa's Negotiated Revolution, Struik, Johannesburg, 1994.

Spies, Philip, "Measuring and Making the Future: The Contribution of Futures Studies to Strategic Thinking in South Africa", Paper delivered at the Second International Conference on Organisational Foresight, University of Strathclyde, UK, August 2004.

Sunter, Clem, The High Road: Where are we now?, Tafelberg Human \& Rousseau, Cape Town, 1996.

Sunter, Clem, The World and South Africa in the 1990s, Human \& Rousseau Tafelberg, Cape Town, 1987.

The Weekly Mail \& the Guardian Weekly, The Mont Fleur Scenarios, 1992.

Tibbs, Hardin, "Pierre Wack: A Remarkable Source of Insight", NETVIEW 9(1), Global Business Network, 1998.

Tucker, Bob and Bruce Scott (eds), South Africa: Prospects for a Successful Transition, Nedcor/Old Mutual Scenarios, Juta \& Co, Cape Town, 1992.

Wack, Pierre, "Scenarios: shooting the rapids", Harvard Business Review NovemberDecember, 1985a.

Wack, Pierre, "Scenarios: uncharted waters ahead", Harvard Business Review SeptemberOctober, 1985b.

Waldmeir, Patti, Anatomy of a Miracle: The End of Apartheid and the Birth of the New South Africa, Norton, New York, 1997.

World Economic Forum, South Africa at 10: Perspectives by political, business and civil leaders, Human \& Rousseau, Cape Town, 2004. 
Abedian, Iraj - former academic, member of GEAR team

Bodibe, Oupa - member ofSA2020 team

Botha, RF (telephone) - former NP government minister

Buys, Jim (telephone) - member of AAC scenario team

Cargill, Jenny - former financial/political journalist

Cassim, Rashad - former academic

Coleman, Colin - former CBM official

Cronin, Jeremy - ANC MP and deputy leader of the SACP

Davies, Rob - member of Mont Fleur scenario team

De Klerk, FW - former RSA President

De Villiers, Dawie - former NP government minister

De Villiers, Fleur (telephone) - former journalist and De Beers executive

Du Plessis, Barend - former NP government minister

Eloff, Theuns - former CEO of CBM and secretary of CODESA

Erwin, Alec - ANC government minister

Esterhuyse, Willie - member of Nedcor/Old Mutual scenario team

Friedman, Steven - political analyst/commentator

Gelb, Stephen - member of Economic Trends group and of GEAR team 
Gnodde, Richard - Goldman Sachs

Godsell, Bobby - member of AAC scenario team

Gouws, Rudolf - member of Nedcor/Old Mutual scenario team

Hirsch, Alan - economic advisor in the Presidency

Kahane, Adam - facilitator of Mont Fleur scenario exercise

Kahane, Dorothy - manager of Mont Fleur scenario exercise

Kaplan, David - academic

Keys, Derek - former NP and GNU government minister

Klein, Lisa - member of SA2020 scenario team

Kouakou, Koffi - academic in futures studies

Landman, JP - member of study steering committee

Le Roux, Michiel - member of Mont Fleur scenario team

Le Roux, Pieter - initiator of Mont Fleur scenario exercise and member of team

Lee, Robin - research coordinator of Nedcor/Old Mutual scenario exercise

Levett, Mike - former chairman of Old Mutual

Lewis, Dave - member of Economic Trends group and of Nedcor/Old Mutual scenario team

Liebenberg, Chris - former MD of Nedcor and GNU government minister

Liebenberg, Johann - member of Mont Fleur scenario team

Mahomed, Hassen - scenario project manager in the Presidency

Makgetla, Neva - ANC and Cosatu economist

Malan, Magnus - former NP government minister

Maphai, Vincent - member of Mont Fleur scenario team

Maree, John - former chairman of Nedcor and of Eskom

Mbeki, Moeletsi - political analyst/commentator

Meyer, Roelf - former NP and GNU government minister

Mohr, Philip - member of Mont Fleur scenario team

Moody-Stuart, Sir Mark (telephone) - former chair, Committee of MDs, Shell

Morobe, Murphy - prominent UDF leader

Naidoo, Jay - former Cosatu Secretary-General 
Naidoo, Jayendra - former Cosatu education officer

Netshitenzhe, Joel - head of the policy unit, Presidency

O'Connell, Brian - member of Mont Fleur scenario team

Ogilvie Thompson, Julian - former AAC chairman

Pahad, Essop - Minister in the Presidency

Porter, Leon - member of Nedcor/Old Mutual scenario team

Ramphele, Mamphela - member of Nedcor/Old Mutual scenario team

Roux, Andre - member of GEAR team

Schlemmer, Laurie - social analyst, associated with Nedcor/Old Mutual exercise

Shubane, Khehla - political analyst

Sicre, Fred - former WEF official

Spicer, Michael - member of AAC scenario team

Spies, Philip - former director of Unit for Futures Research, University of Stellenbosch

Stals, Chris - former DG of Department of Finance and SARB Governor

Stemmet, AP - former coordinator of the secretariat of the State Security Council

Sunter, Clem - member of AAC scenario team

Taljaard, Raenette - member of SA2020 scenario team

Taylor, Viviene - member of Mont Fleur scenario team

Tibbs, Hardin (correspondence) - former colleague of Pierre Wack

Tucker, Bob - chairman of Nedcor/Old Mutual scenario project

Van der Horst, Johannes - former GM of Old Mutual

Van der Merwe, Sue - member of Mont Fleur scenario team

Van Niekerk, Gerhard - former GM of Old Mutual

Van Zyl Slabbert, Frederik - former politician, associated with Nedcor/Old Mutual exercise

Wilson, Peter - facilitator of SA2020 exercise 


\section{ANNEX B: Nedcor/Old Mutual Scenario Team}

F Cassim

Wits Business School

Economic advisor to the ANC

Gerhard Croeser

Department of Finance

Sholto Cross

Consultant, World Bank/UNDP

Oscar Dhlomo

Institute for Multi-Party Democracy

Willie Esterhuyse

University of Stellenbosch

Rudolph Gouws

Rand Merchant Bank

Kenneth Hartshorne

Educationist

R Hunter

PLANACT
W de Klerk

Rand Afrikaans University

Robin Lee

Development consultant

Rob Lee

Old Mutual

Dave Lewis

University of Cape Town

Economic Trends Research Group

J Messerschmidt

Eskom

M Motonyane

Tribune magazine

Reg Munro

Old Mutual

Leon Porter

Nedcor 
Mamphela Ramphele

University of Cape Town

Bruce Scott

Harvard Business School

Charles Simkins

University of the Witwatersrand
Charles Stride

Fisher Hoffman Stride and Co

Rob Tucker (chairman)

Nedcor

Pierre Wack

Scenario consultant 


\section{ANNEX C: Mont Fleur Scenario Team}

Dorothy Boesak

Project manager

Rob Davies

SACP

University of the Western Cape

Howard Gabriels

Former trade unionist

Adam Kahane

Project facilitator

Koosum Kalyan

Shell South Africa

Michiel le Roux

Former MD of Distillers

Pieter le Roux

University of the Western Cape

Johann Liebenberg

Chamber of Mines of South Africa
Saki Macozoma

National Executive Committee, ANC

Tito Mboweni

Department of Economic Policy, ANC

Gaby Magomola

Chairman, Inter-Africa Group

Mosebyane Malatsi

PAC

Development Bank of Southern

Africa

Thobeka Mangwana

University of the Western Cape

Trevor Manuel

National Executive Committee and Department of Economic Policy, ANC

Vincent Maphai

University of the Western Cape 
Philip Mohr

University of South Africa

Nicky Morgan

University of the Western Cape

Patrick Ncube

University of Cape Town

Gugile Nkwinti

National Executive Committee and

Eastern Cape Regional Secretary,

ANC

Brian O'Connell

Peninsula Technikon

Mahlomola Skosana

Trade unionist
Viviene Taylor

University of the Western Cape

Sue van der Merwe

National Executive Committee,

Black Sash

Christo Wiese

Chairman of Pepkor

Member of the President's

Economic Advisory Council

Winfried Veit

Friedrich Ebert Stiftung 


\section{ANNEX D: South African Scenarios}

\section{Thumbnail Sketches}

\begin{tabular}{|c|c|}
\hline Title & The Knowledge-Intensive Services Business in 2007 \\
\hline Short description & $\begin{array}{l}\text { A scenario exercise, based on the ability of the economy to generate and } \\
\text { assimilate the innovation necessary to grow knowledge-based industry. }\end{array}$ \\
\hline Type of study & Scenario exercise \\
\hline Date & 1997 \\
\hline Author & CSIR \\
\hline Funder & CSIR \\
\hline Dissemination & \\
\hline Available from: & On application to the CSIR \\
\hline Long description & $\begin{array}{l}\text { The exercise was intended to scope the potential for development of } \\
\text { knowledge-intensive businesses in South Africa, including the CSIR itself. } \\
\text { Major players and markets in the knowledge-intensive sector were identified, } \\
\text { and the potential development paths of such markets assessed. Outcomes } \\
\text { were mapped based on the ability of the economy to develop and assimilate } \\
\text { innovation. The exercise generated four scenarios: } \\
\text { - Renaissance revisited: South Africa sees a high rate of availability of } \\
\text { innovation in knowledge-based services, and displays a high ability to } \\
\text { assimilate such knowledge-intensive innovation. Economic growth is } \\
\text { substantial and shared evenly among the population. }\end{array}$ \\
\hline
\end{tabular}




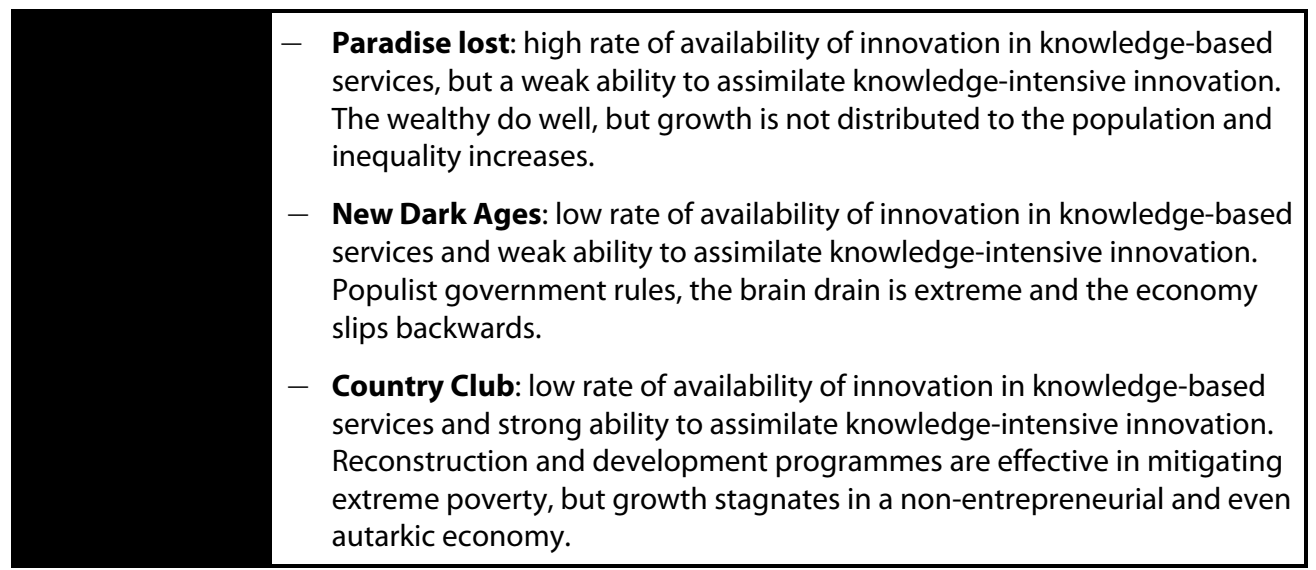

\begin{tabular}{|c|c|}
\hline Title & The Future of the Unions - The September Scenarios \\
\hline Short description & $\begin{array}{l}\text { Three scenarios examining the uncertainties facing the South African trade } \\
\text { union movement in a post-apartheid society. }\end{array}$ \\
\hline Type of study & Scenario building \\
\hline Date & August 97 \\
\hline Author & $\begin{array}{l}\text { The September Commission, reporting to COSATU (the Congress of South } \\
\text { African Trade Unions). }\end{array}$ \\
\hline Funder & COSATU \\
\hline Dissemination & $\begin{array}{l}\text { The report was disseminated internally at COSATU, as part of a strategic } \\
\text { exercise at the union. }\end{array}$ \\
\hline Available from: & http://www.cosatu.org.za/congress/sept-ch1.htm \\
\hline Long description & $\begin{array}{l}\text { The September scenarios analysed the implications of the post-democracy } \\
\text { landscape for the trade union movement. In the words of the September } \\
\text { Commission itself, COSATU was "born in the struggle against apartheid, as a } \\
\text { component in the broad national liberation movement." } 1994 \text { thus brought } \\
\text { about a major change in the way the organisation perceived itself, and in its } \\
\text { relevance to South African society. } \\
\text { The Commission identified the following key uncertainties for the unions: } \\
\text { - } \text { the extent and nature of economic development } \\
\text { - } \text { the nature of the labour market, i.e., what kind of workplaces and jobs will } \\
\text { we be organising in } 2005 \text { ? how many workers will be unemployed? } \\
- \text { the vision and programme of the ANC } \\
\text { - the nature and strategies of the capitalist class }\end{array}$ \\
\hline
\end{tabular}




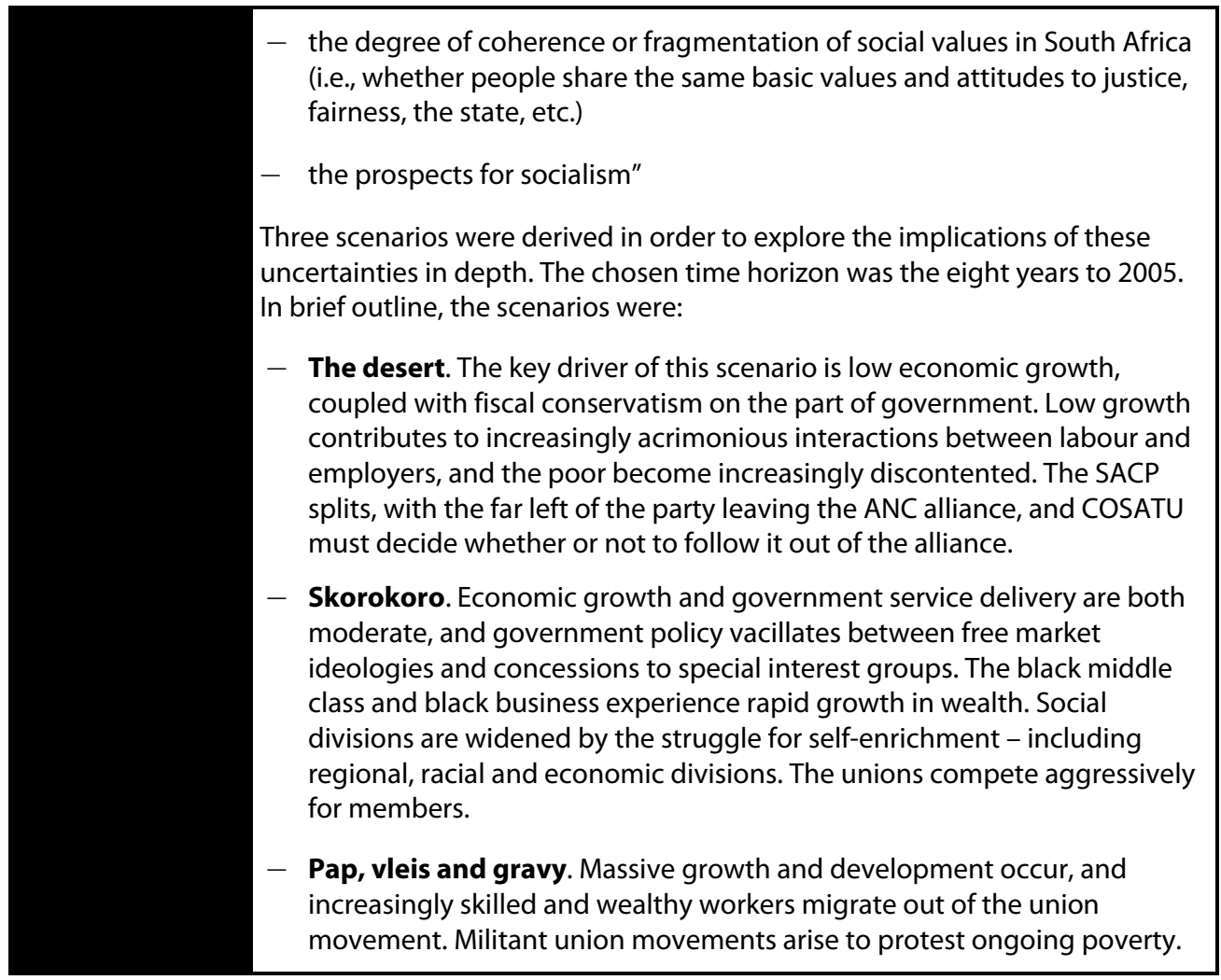

\begin{tabular}{|c|c|}
\hline Title & PSG/Siphumelele Three Scenarios \\
\hline Short description & $\begin{array}{l}\text { Three economic and political scenarios, prepared by PSG and Siphumelele, } \\
\text { with the explicit intention of influencing policy thinking in the run-up to the } \\
1999 \text { elections }\end{array}$ \\
\hline Type of study & Scenario building \\
\hline Date & 1998 \\
\hline Author & $\begin{array}{l}\text { PSG Group Limited and Siphumelele Investments Limited, with Pieter le Roux } \\
\text { as facilitator }\end{array}$ \\
\hline Funder & PSG Group Limited and Siphumelele Investments Limited \\
\hline Dissemination & \\
\hline Available from: & \\
\hline Long description & $\begin{array}{l}\text { In } 1998 \text { the PSG Group and Simpumelele Investments undertook a political } \\
\text { and economic scenario exercise explicitly intended to assist strategic thinking } \\
\text { in the policy environment. The } 1999 \text { elections seem to have been a focus of } \\
\text { the report. The exercise generated three scenarios: }\end{array}$ \\
\hline
\end{tabular}




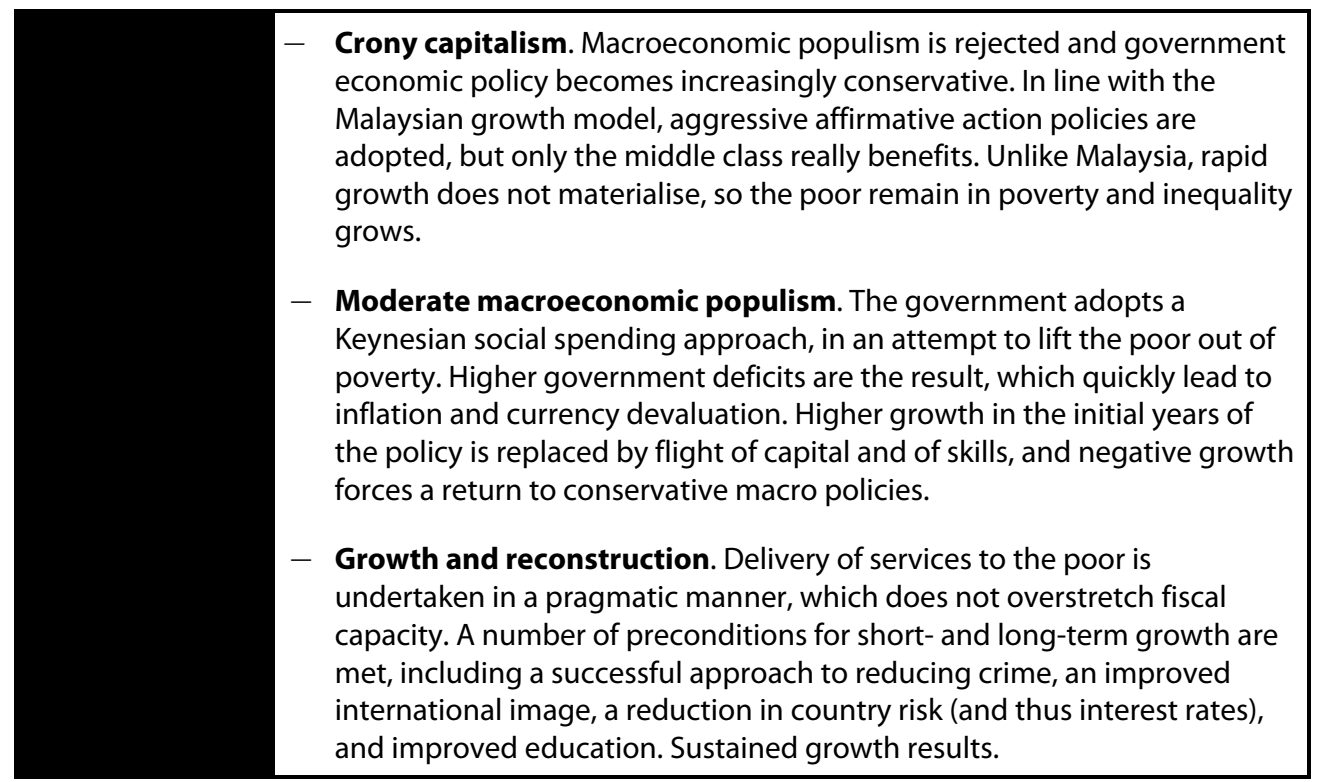

\begin{tabular}{|c|c|}
\hline Title & Department of Science and Technology Foresight Studies \\
\hline Short description & $\begin{array}{l}\text { The National Research and Technology Foresight research process was } \\
\text { designed to provide content for the process of creating a national system of } \\
\text { innovation in South Africa, by identifying sectoral priorities and goals. }\end{array}$ \\
\hline Type of study & Foresight studies \\
\hline Date & 2000 \\
\hline Author & SA Department of Science and Technology \\
\hline Funder & SA Department of Science and Technology \\
\hline Dissemination & \\
\hline Available from: & http://www.dst.gov.za/foresight_reports/index.php \\
\hline Long description & $\begin{array}{l}\text { The Department of Science and Technology undertook the foresight exercise } \\
\text { in order to flesh out the planned creation of a national system of innovation. } \\
\text { The process involved approximately } 350 \text { working-group members drawn } \\
\text { from industry. The intention is to repeat the exercise as necessary. } \\
\text { The } 12 \text { sectors considered to be of greatest importance were examined, } \\
\text { ranging from tourism to biodiversity to mining and metallurgy. The research } \\
\text { and technology base of each sector was described, and recommendations for } \\
\text { the future were made. These were at both a sector level and a generic level, } \\
\text { and ranged across infrastructure development, institutional development and } \\
\text { superstructure development. A 20-year time horizon for outcomes was } \\
\text { assumed. }\end{array}$ \\
\hline
\end{tabular}




\begin{tabular}{|c|c|}
\hline Title & Electricity Market Scenarios Study \\
\hline Short description & $\begin{array}{l}\text { An analysis of the impact of competition on the South African electricity } \\
\text { market, with suggestions for appropriate market structure }\end{array}$ \\
\hline Type of study & Scenario outcome of industry workshop \\
\hline Date & Feb 2001 \\
\hline Author & $\begin{array}{l}\text { The National Electricity Regulator, in conjunction with Norwegian consulting } \\
\text { group ECON, their British partners PPA and their South African partners SAD- } \\
\text { ELEC }\end{array}$ \\
\hline Funder & The Norwegian Government \\
\hline Dissemination & \\
\hline Available from: & http://www.ner.org.za/documents/Econ\%20Report\%20web.CV.pdf \\
\hline Long description & $\begin{array}{l}\text { The scenario project was undertaken at a point when the National Electricity } \\
\text { Regulator was heavily involved in policy debates as to the future structure of } \\
\text { the industry. Key uncertainties included the degree to which competition } \\
\text { should be allowed in the market, the implications of doing so, and the } \\
\text { mechanisms by which competition could be introduced. The scenarios aimed } \\
\text { to inform policy-makers about the key decisions needed during this process. } \\
\text { Two scenarios were generated: } \\
\text { - A "fast-track" scenario, with swift decisions to move towards a } \\
\text { competitive market structure, implemented rapidly. The key priorities for } \\
\text { the NER in this scenario were identified as establishing the ability to } \\
\text { monitor competition conditions, putting in place incentive regulation for } \\
\text { network tariffs and setting up an appropriate interface with the } \\
\text { transmission system operator. } \\
\text { - A "slow-track" scenario, where the pace of reform is slower, and there is } \\
\text { prolonged uncertainty about final market structure. In this case, priorities } \\
\text { for the NER will include refining the basis for regulating the wholesale } \\
\text { electricity pricing system, establishing a strategy for licensing investments } \\
\text { and, again, setting up an appropriate interface with the transmission } \\
\text { system operator. }\end{array}$ \\
\hline
\end{tabular}

\begin{tabular}{|c|c|}
\hline Title & Southern African 2020: Five Different Scenarios \\
\hline Short description & $\begin{array}{l}\text { A scenario exercise mapping the impact of the demise of apartheid on the } \\
\text { SADC region }\end{array}$ \\
\hline Type of study & Scenario building \\
\hline Date & 2002 \\
\hline Author & Institute for Global Dialogue and the Friedrich Ebert Foundation \\
\hline Funder & The Friedrich Ebert Foundation \\
\hline
\end{tabular}




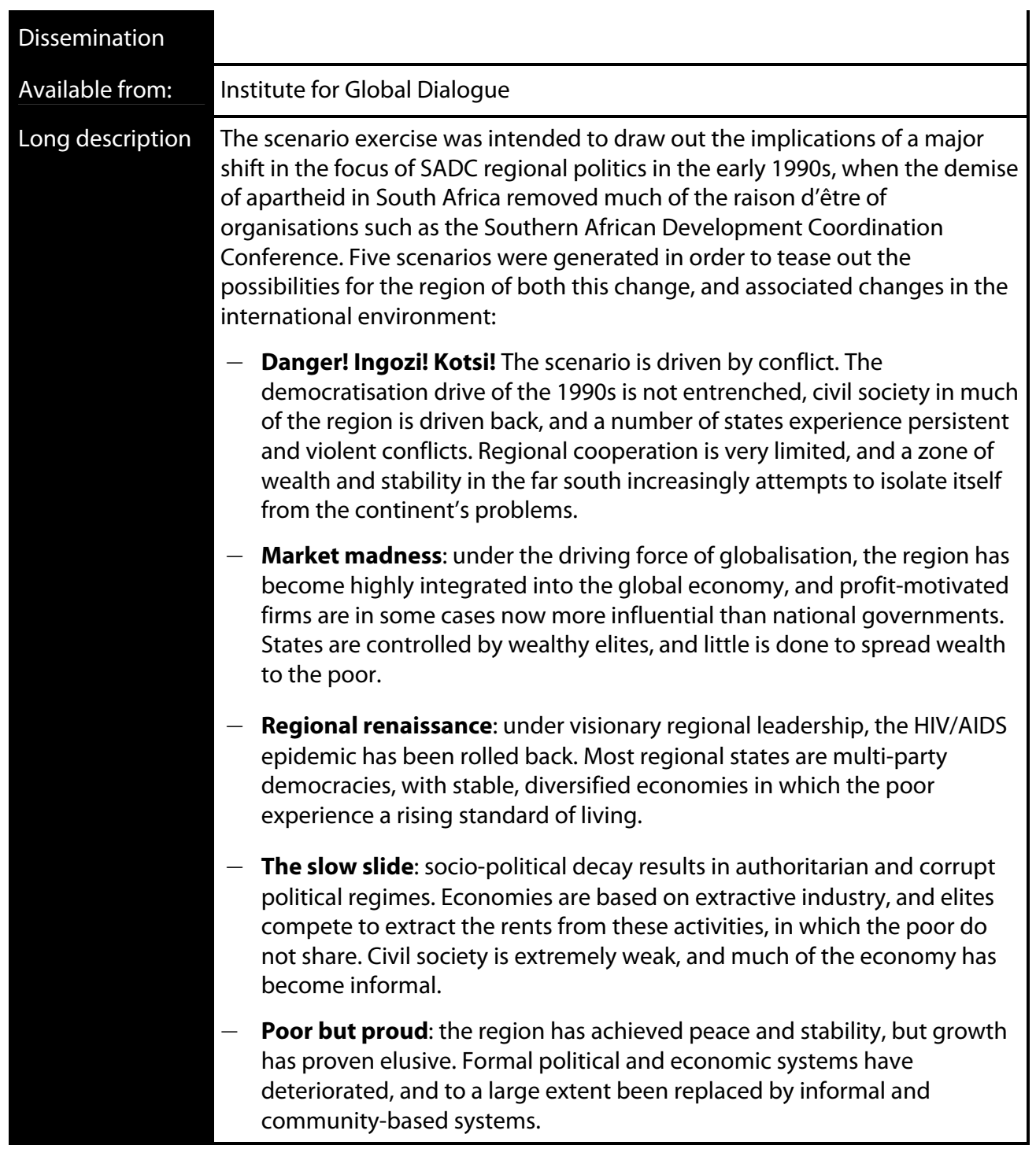

\begin{tabular}{|l|l|}
\hline Title & $\begin{array}{l}\text { CSIR Strategy 2014: South African Science-based Organisation providing } \\
\text { Technological Innovation }\end{array}$ \\
\cline { 2 - 2 } Short description & $\begin{array}{l}\text { An internal strategic scenario exercise conducted as part of the CSIR's wider } \\
\text { strategic planning initiatives }\end{array}$ \\
\cline { 2 - 2 } & Sype of study \\
Date & Scenario building \\
\hline Author & CSIR \\
\hline
\end{tabular}




\begin{tabular}{|c|c|}
\hline Funder & CSIR \\
\hline Dissemination & Internal only \\
\hline Available from: & On application to the CSIR \\
\hline Long description & $\begin{array}{l}\text { Key drivers for the CSIR were identified as developing an African identity; } \\
\text { creating an enabling environment for innovation, managing knowledge } \\
\text { relationships and retaining talent. Five scenarios were developed: } \\
\text { - South Africa Watering the Gardens of the World: the CSIR succeeds in } \\
\text { managing knowledge relationships and retaining talent, but fails in other } \\
\text { areas. Although the education system produces talented innovators, } \\
\text { there are limited local opportunities for them and many emigrate. } \\
\text { - South Africa - Greenhouse to the World: African identity is fostered and } \\
\text { the environment is innovation-enabling, but other areas are neglected. } \\
\text { Local scientific advances are based on imported talent, with little } \\
\text { knowledge transfer locally. } \\
\text { - Death in the Thirstland: all four key drivers fail to develop. Educational } \\
\text { systems fail to deliver talented innovators and what talent there is tends } \\
\text { to emigrate. The CSIR is either dominated by irrelevant politicised } \\
\text { research agendas or closes entirely. The economy stagnates. } \\
\text { - Everything in the South Africa garden is lovely: the CSIR succeeds on } \\
\text { most fronts, but fails to establish a truly South African identity. Local } \\
\text { innovation flourishes and is implemented locally as well. Domestic growth } \\
\text { is supported, but little trickle down into the rest of Africa is experienced. } \\
\text { - Africa becomes a Garden: success is met on all four key drivers. The } \\
\text { African intellectual diaspora returns and innovation is nurtured by local } \\
\text { talent. }\end{array}$ \\
\hline
\end{tabular}

\begin{tabular}{|c|c|}
\hline Title & SADC 2015 Scenarios: CSIR Infrastructure Thrust in support of NEPAD \\
\hline Short description & $\begin{array}{l}\text { Four scenarios were derived in order to highlight key uncertainties as regards } \\
\text { the development of a macro infrastructure methodology, in support of the } \\
\text { socioeconomic development objectives of NEPAD. }\end{array}$ \\
\hline Type of study & Scenario building \\
\hline Date & 2003 \\
\hline Author & CSIR (The Council for Scientific and Industrial Research) \\
\hline Funder & CSIR \\
\hline Dissemination & \\
\hline Available from: & http://www.buildnet.co.za/akani/2003/jul/04_scenarios.pdf \\
\hline
\end{tabular}




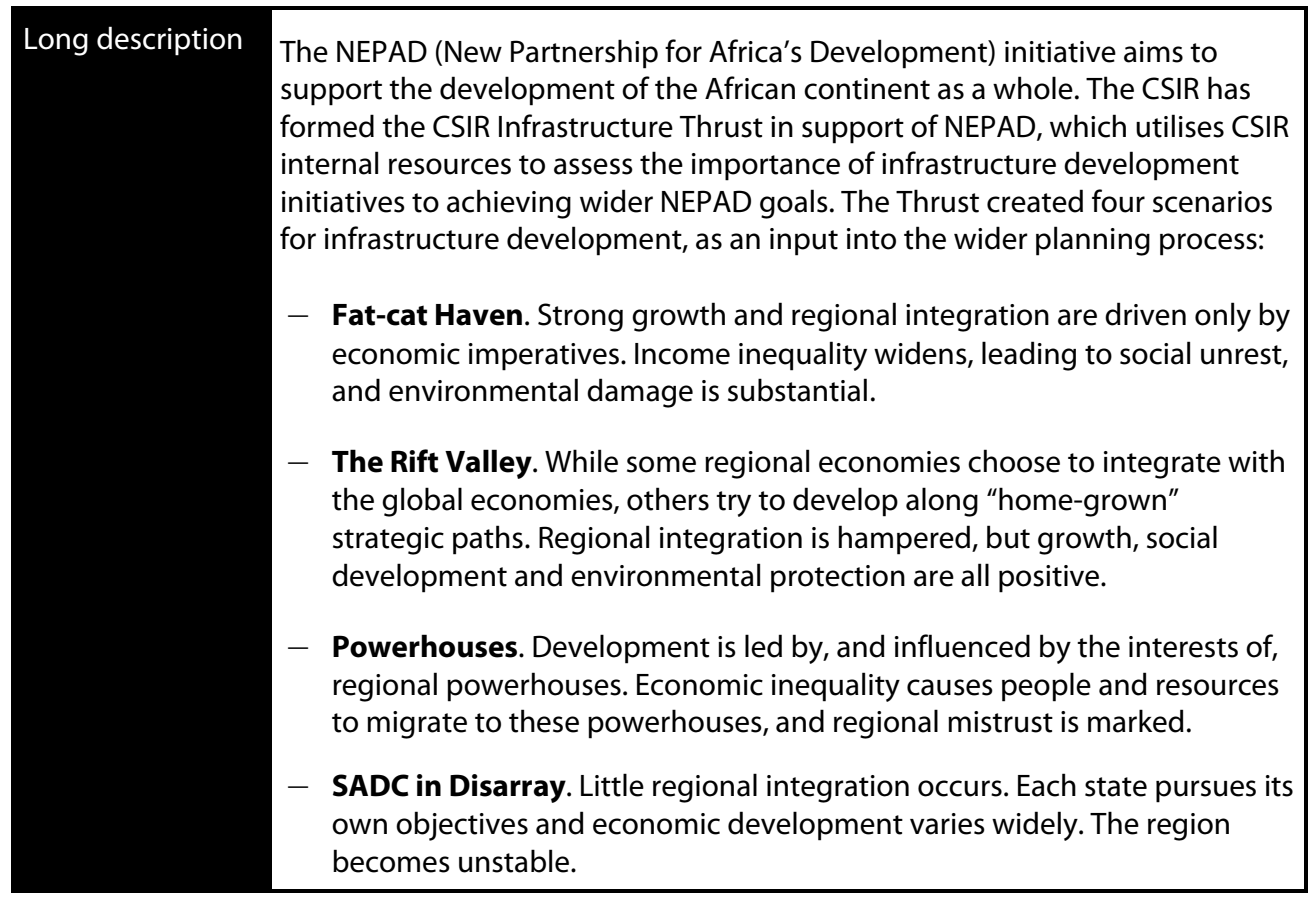

\begin{tabular}{|c|c|}
\hline Title & CSIR Energy Scenarios for Africa \\
\hline Short description & $\begin{array}{l}\text { The African continent does not at present provide sufficient energy for the } \\
\text { needs of its inhabitants. The scenario exercise was designed to tease out the } \\
\text { implications of this, in the framework of a declining global supply of fossil } \\
\text { fuels. }\end{array}$ \\
\hline Type of study & Scenario building \\
\hline Date & 2003 \\
\hline Author & CSIR and Shell \\
\hline Funder & CSIR \\
\hline Dissemination & \\
\hline Available from: & $\begin{array}{l}\text { An abbreviated version of the original paper is available at } \\
\text { http://www.businessinafrica.net/energy_in_africa/340746.htm }\end{array}$ \\
\hline Long description & $\begin{array}{l}\text { The availability of affordable and reliable energy is key to meeting the } \\
\text { economic and social development goals of NEPAD. At the same time, energy } \\
\text { production has the potential to cause substantial environmental damage, and } \\
\text { the global supply of fossil fuels is dwindling. The scenarios teased out the } \\
\text { implications of these trends for the wider achievement of development goals } \\
\text { in Africa. Three scenarios were developed: } \\
\text { - Africa Walking Tall: continental co-operation on an Africa-first basis }\end{array}$ \\
\hline
\end{tabular}


- Africa Learning to Walk: some regional co-operation

- South Africa First: limited regional cooperation, with South African development setting the pace

\begin{tabular}{|c|c|}
\hline Title & Africa 2025: What Possible Futures For Sub-Saharan Africa? \\
\hline Short description & $\begin{array}{l}\text { The exercise represents a continuation of the work of the UNDP's African } \\
\text { Futures Institute, which had undertaken country futures studies in } 20 \text { African } \\
\text { countries. The research provides futures analysis for sub-Saharan Africa as a } \\
\text { whole, looking forward to } 2015 \text {. }\end{array}$ \\
\hline Type of study & Exploratory scenario building \\
\hline Date & 2003 \\
\hline Author & The UNDP African Futures Institute \\
\hline Funder & Bilateral and multilateral donors, including the UNDP, France and Canada. \\
\hline Dissemination & \\
\hline Available from: & $\begin{array}{l}\text { In booklet form, available from the African Futures Institute and published by } \\
\text { Unisa Press. }\end{array}$ \\
\hline Long description & $\begin{array}{l}\text { The scenarios were developed in order to explore possible long-term } \\
\text { outcomes for sub-Saharan Africa. New trends on the continent, such as the } \\
\text { growing move from socialist to capitalist economic systems, were included. } \\
\text { The work built on the progress made by the UNDP's African Futures Institute, } \\
\text { which had previously completed country futures studies in } 20 \text { African } \\
\text { countries. } \\
\text { Four scenarios were developed: } \\
\text { - The lions are trapped. Economic growth is very slow or non-existent, and } \\
\text { minimal integration into the global economic system has occurred. The } \\
\text { continent remains primarily an exporter of raw materials, despite } \\
\text { declining profitability, and provision of public services remain inadequate. } \\
\text { However, crisis and collapse are averted. } \\
\text { - The lions are hungry. External shocks, such as decreased raw material } \\
\text { prices and lower aid flows, destabilise a number of countries. Regional } \\
\text { institutions are unable to deal with this instability and violence spreads. } \\
\text { - The lions come out of their den. The provision of public services, } \\
\text { education in particular, improves sharply. Together with infrastructure } \\
\text { improvements and a favourable international environment, this supports } \\
\text { sustained economic growth. } \\
\text { - The lions mark their territory. Economic growth occurs along a uniquely } \\
\text { African growth path. }\end{array}$ \\
\hline
\end{tabular}




\begin{tabular}{|c|c|}
\hline Title & $\begin{array}{l}\text { Southern African Scenarios 2015: Renaissance, Asymmetry or Decline } \\
\text { and Decay }\end{array}$ \\
\hline Short description & Scenarios as regards the policy priorities for SADC in the medium term \\
\hline Type of study & Scenario building \\
\hline Date & 2003 \\
\hline Author & The South African Institute of International Affairs (SAIIA) \\
\hline Funder & The Canadian International Development Agency (CIDA) \\
\hline Dissemination & \\
\hline Available from: & SAIIA \\
\hline Long description & $\begin{array}{l}\text { The scenario exercise aimed to identify policy priorities for the SADC region in } \\
\text { the 5- to 15-year time frame. Three scenarios were identified: } \\
\text { - } \text { Renaissance: the regional economy is increasingly integrated into the } \\
\text { global economy, and the benefits of improved growth are distributed to } \\
\text { the poor. Crime, instability and disease (e.g. HIV) are all effectively dealt } \\
\text { with. Regional institutions such as Nepad and SADC all deliver on their } \\
\text { mandates. } \\
\text { - Asymmetry: globalisation benefits the wider economies of the region, } \\
\text { but decreases employment in many sectors. Crime, instability and disease } \\
\text { are contained, but continue to have an impact on regional development, } \\
\text { and regional institutions achieve only limited progress. } \\
\text { - Decline and decay: SADC becomes a marginal player in the global } \\
\text { economy and economic progress is weak. Crime, instability and disease } \\
\text { proceed unchecked, democracy falters and regional institutions largely } \\
\text { fail. }\end{array}$ \\
\hline
\end{tabular}

\begin{tabular}{|l|l|}
$\begin{array}{ll}\text { Title } \\
\text { Short description }\end{array}$ & $\begin{array}{l}\text { The scenario exercise formed part of the government's review of ten years of } \\
\text { freedom, and formulated possible outcomes for the second decade of } \\
\text { freedom. }\end{array}$ \\
\hline $\begin{array}{l}\text { Type of study } \\
\text { Date }\end{array}$ & $\begin{array}{l}\text { Scenario building } \\
\text { Author }\end{array}$ \\
Funder & South Africa, Office of the President \\
\hline Dissemination & $\begin{array}{l}\text { South African government } \\
\text { Internal government distribution - a summary of the report was distributed } \\
\text { publicly, but the full document remains confidential. }\end{array}$ \\
\hline
\end{tabular}




\begin{tabular}{|c|c|}
\hline Available from: & $\begin{array}{l}\text { The full version of the report is not publicly available. A short description can } \\
\text { be found at http://www.10years.gov.za/review/statements/10dec03.htm }\end{array}$ \\
\hline Long description & $\begin{array}{l}\text { In late } 2003 \text { the government undertook a review of progress made during the } \\
\text { decade after the first democratic election in 1994. As part of the review } \\
\text { process, scenarios postulating possible outcomes for the next decade were } \\
\text { completed as an aid to policy planning. On the assumption that the two } \\
\text { guiding forces for South Africa would be the global environment and internal } \\
\text { social cohesion, four scenarios were generated: } \\
\text { - S'gudi S'nais. The global environment is accommodating, but South } \\
\text { Africa fails to take advantage of the opportunity to decrease social } \\
\text { inequality. Income inequality is ultimately associated with low sustainable } \\
\text { growth rates. } \\
\text { - Dulisanang. Despite global insecurities and economic crisis, South Africa } \\
\text { emerges as a socially cohesive and peaceful society. However, growth is } \\
\text { limited, which inhibits service delivery. } \\
\text { - Skedonk. Not only is the global environment deeply hostile, but the } \\
\text { social divisions in South Africa are deepened. Government policy } \\
\text { responses are highly inadequate. } \\
\text { - Shosholoza. Global growth and stability support domestic growth and } \\
\text { stability. }\end{array}$ \\
\hline
\end{tabular}

\begin{tabular}{|c|c|}
\hline Title & AIDS in Africa: Three scenarios to 2025 \\
\hline Short description & $\begin{array}{l}\text { The project explores three different potential outcomes of the HIV/AIDS } \\
\text { pandemic in Africa, over the next twenty years. }\end{array}$ \\
\hline Type of study & Scenario building \\
\hline Date & 2005 \\
\hline Author & UNAIDS, assisted by Royal Dutch/Shell Group \\
\hline Funders & $\begin{array}{l}\text { The African Development Bank, Becton Dickinson, the Bill and Melinda Gates } \\
\text { Foundation, Merck \& Co, Pfizer Inc, Rockefeller Foundation, Royal Dutch/Shell } \\
\text { Group, Swedish International Development Agency, United Nations } \\
\text { Development Program, United Nations Economic Commission for Africa, } \\
\text { Development Corporation Ireland, SIDA, Department for International } \\
\text { Development (DFID), the United States Agency for International Development } \\
\text { (USAID), and the Canadian International Development Agency (CIDA) }\end{array}$ \\
\hline \multicolumn{2}{|l|}{ Dissemination } \\
\hline Available from: & $\begin{array}{l}\text { http://www.unaids.org/unaids_resources/images/AIDSScenarios/AIDS- } \\
\text { scenarios- } \\
\text { 2025_report_en.pdf\#search=\%22aids\%20in\%20africa\%20unaids\%22 }\end{array}$ \\
\hline
\end{tabular}




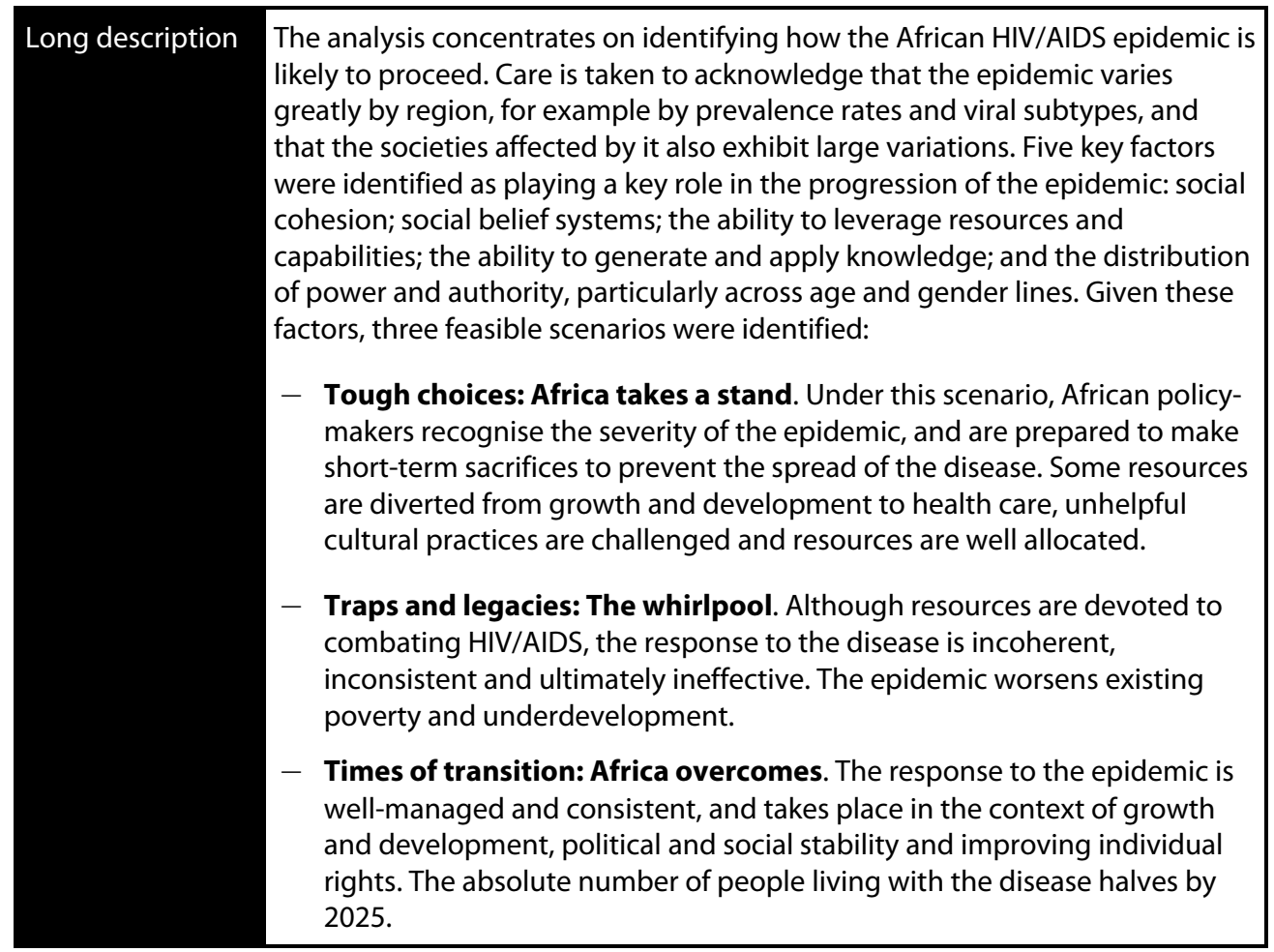

\begin{tabular}{|c|c|}
\hline Title & Zimbabwe: A Pre-Election Overview and Recovery Scenarios \\
\hline Short description & $\begin{array}{l}\text { The report emphasises the economic and social deterioration experienced by } \\
\text { Zimbabwe in recent years, and identifies the changes that will be necessary to } \\
\text { restore prosperity to the country and its citizens. }\end{array}$ \\
\hline Type of study & Identification of necessary conditions for change \\
\hline Date & March 2005 \\
\hline Author & Dianna Games for the South African Institute of International Affairs (SAllA) \\
\hline Funder & SAIIA \\
\hline Dissemination & \\
\hline Available from: & $\begin{array}{l}\text { http://saiia.org.za/images/upload/ZimbabweRecoveryScenarios2005- } \\
\text { Games.pdf }\end{array}$ \\
\hline
\end{tabular}


The story of South Africa's transition in 1994 to a non-racial democracy has been told many times, principally from the perspective of the political forces for change. But many other factors were at work, over many years, which influenced not only the political outcome but also the economic philosophy of the new ANC government.

This pioneering study explores one such set of factors, viz the ideas generated by three quite different privately initiated but publicly disseminated scenario exercises undertaken in the period 1985-1992. In doing so, and in locating the scenarios within the turbulent context of the times, it offers fresh and compelling insights into the transition as well as into the fierce contestation over political and economic ideas, which continues to the present day.

The book goes beyond this. It draws on South Africa's unusually rich experience of scenario work to illuminate the circumstances in which the method can be fruitfully used as well as the key factors that must be taken into account in designing, conducting and communicating the project's output. And it points to the piffalls if these matters are not properly addressed.

Nick Segal has had a varied career. He has held senior positions in the World Bank in Washington DC and in a major consultancy in the City of London and was the founder of SQW, an economic development and public policy consultancy headquartered in Cambridge, England. In South Africa he has been a director of mining companies (and served as the president of the Chamber of Mines) and dean/director of the Graduate School of Business at the University of Cape Town, and is currently an extraordinary professor at the Gordon Institute of Business Science of the University of Pretoria. He was a member of the Presidential Labour Market Commission in the mid-1990s and of the first Council on Higher Education. He has published widely, the best known being The Cambridge Phenomenon: The Growth of High Technology Industry in a University Town (1985). 